\title{
TWORZENIE WARTOŚCI W SPÓŁKACH GIEŁDOWYCH Z WIELKOPOLSKI
}

\section{WSTĘP}

Rozważania podjęte w artykule dotyczą efektywności przedsiębiorstw regionu i wpisują się $\mathrm{w}$ szeroko rozumianą problematykę zarządzania miastem, zważywszy na fakt, że efektywność przedsiębiorstw w regionie jest elementem warunkujacym rozwój miasta, a rozpoznanie i wspieranie potencjału gospodarczego terytorium stanowi jeden z kluczowych problemów zarządzania miastem. W sposób bardziej szczegółowy podjętą problematykę efektywności podmiotów gospodarczych umiejscowić należy w ramach koncepcji zarządzania wartością przedsiębiorstwa (VBM - value-based management $)^{1}$, przyjmującej tworzenie wartości za cel funkcjonowania przedsiębiorstw w gospodarce rynkowej ${ }^{2}$. Celem pracy jest pomiar i ocena dokonań spółek giełdowych z Wielkopolski w zakresie osiaganiu celu działania przedsiębiorstwa według koncepcji zarządzania przez wartość.

Zakres przedmiotowy pracy określa koncepcja VBM, a w szczególności pomiar dokonań w ramach tej koncepcji. Zakres podmiotowy ogranicza rozważania do wielkopolskich spółek giełdowych, przez które rozumie się spółki akcyjne mające siedzibę na terenie województwa wielkopolskiego, notowane na Giełdzie Papierów Wartościowych w Warszawie. Zakres czasowy badań obejmuje lata 2010-2013.

W części empirycznej pracy wykorzystano mierniki wartości kreowanej, służące do pomiaru rezultatów różnych faz procesu tworzenia wartości przez przedsiębiorstwo, takie jak zysk ekonomiczny (EP - economic profit) czy war-

\footnotetext{
${ }^{1}$ Nazywanej też w polskiej literaturze zarządzaniem przez wartość.

${ }^{2}$ Rozważania na temat celu działania przedsiębiorstwa są istotnym elementem tworzacym teoretyczne podstawy koncepcji VBM. Cel przedsiębiorstwa w ramach tej koncepcji definiuje się m.in. jako maksymalizację wartości rynkowej przedsiębiorstwa, maksymalizację wartości dla właścicieli czy „szukanie” wartości. Por. np. A. Rappaport, Wartość dla akcjonariuszy: poradnik menedżera i inwestora, WIG-Press, Warszawa 1999, s. 1; M. C. Jensen, Value Maximization, Stakeholder Theory, and the Corporate Objective Function, „Journal of Applied Corporate Finance” 14, 2001, nr 3, Fall, s. 11; M. Michalski, Ekonomiczna wartość dodana dla właścicieli, w: J. Duraj (red.), Wartość przedsiębiorstwa - z teorii i praktyki zarzqdzania, Novum, Płock 2000, s. 69; T. Waśniewski, W. Skoczylas, Teoria i praktyka analizy finansowej w przedsiębiorstwie, Fundacja Rozwoju Rachunkowości w Polsce, Warszawa 2002, s. 373; E. A. Helfert, Techniki analizy finansowej, PWE, Warszawa 2004, s. 21; E. F. Brigham, L. C. Gapenski, Zarządzanie finansami, t. 2, PWE, Warszawa 2000, s. 44.
} 
tość wytworzona dla akcjonariuszy (CSV - created shareholder value). Poza tym wykorzystano miary korelacji jako metody analizy współzależności zjawisk oraz metodę kolejnych podstawień, która jest jedną z metod deterministycznych analizy przyczynowej w analizie ekonomicznej przedsiębiorstwa. Dane dotyczace wielkopolskich spółek giełdowych pozyskano z serwisów EMIS $^{3}$ (jednostkowe raporty finansowe opracowane przez spółkę Notoria) oraz Stooq.pl (dane giełdowe). Do przygotowania danych oraz przeprowadzenia obliczeń wykorzystano oprogramowanie Statistica oraz Excel (za pomoca procedur napisanych w języku programowania Visual Basic for Applications).

\section{ZNACZENIE I PODSTAWY TEORETYCZNE PODJĘTEGO TEMATU}

Znaczenie podejmowanego tematu dla problematyki zarządzania miastem jest nie do przecenienia. Wyniki badań przedstawionych w opracowaniu wpisują się w nurt rozważań nad efektywnością przedsiębiorstw. Podkreślić należy, że efektywność przedsiębiorstw w regionie jest elementem warunkującym rozwój regionalny, jak również rozwój miasta ${ }^{4}$. Efektywność i gospodarność to także cechy dobrego planu zarządzania, bez którego właściwe zarządzanie miastem nie jest możliwe ${ }^{5}$. Także konieczność rozwoju przedsiębiorczości w mieście nie budzi wątpliwości ${ }^{6}$, a rozpoznanie i wspieranie potencjału gospodarczego terytorium, również w kontekście atrakcyjności miasta i obszaru metropolitalnego, stanowi jeden z kluczowych problemów zarządzania miastem ${ }^{7}$. Ponadto efektywność przedsiębiorstw działających na terenie miasta i regionu ma bezpośredni wpływ na wysokość podatków stanowiących dochody własne w ramach dochodów bieżaccych budżetu miasta, co warunkuje możliwości finansowe nim zarządzających, a także wpływ pośredni poprzez tworzenie miejsc pracy dla mieszkańców oraz tworzenie ogólnego klimatu inwestycyjnego.

Zważywszy na fakt, że Wielkopolska to region Polski tradycyjnie kojarzony z przedsiębiorczościa, gospodarnością i oszczędnościa, interesująca wydaje się odpowiedź na pytanie, czy wielkopolskie przedsiębiorstwa tworzą wartość, czy przekazują ją właścicielom, jak również, co zmiany tej wartości determinuje. Ze względu na dostępność danych w artykule problematykę tworzenia war-

\footnotetext{
${ }^{3}$ Dostępne na: site.securities.com (dostęp: 24.10.2014).

${ }^{4}$ Por. M. J. Nowak, Czynniki prorozwojowe w procesie zarzadzania miastem, „Współczesne Zarządzanie” 2011, nr 1, s. 62-63; J. Parysek, Miasta polskie na przełomie XX i XXI wieku. Rozwój i przeksztatcenia strukturalne, Bogucki Wyd. Naukowe, Poznań 2005, s. 82-98.

${ }_{5}^{5}$ Por. T. Markowski, D. Stawasz, Ekonomiczne i środowiskowe aspekty zarzadzania rozwojem miast i regionów, WN UŁ, Łódź 2001, s. 187-188.

${ }^{6}$ Por. J. Dominiak, Struktura przestrzenna komercyjnych ustug dla biznesu $w$ aglomeracji poznańskiej, w: J. Słodczyk, R. Klimek (red.), Przemiany przestrzeni miast i stref podmiejskich, UO, Opole 2006, s. 53-62.

7 Por. A. Noworól, Zarzadzanie miastem-podstawy teoretyczne, w: B. Kożuch, C. Kochalski (red.), Strategiczne zarzadzanie miastem $w$ teorii i praktyce Urzędu Miasta Poznania, Monografie i Studia Instytutu Spraw Publicznych Uniwersytetu Jagiellońskiego, Kraków 2011, s. 34-35.
} 
tości w przedsiębiorstwach odniesiono do wielkopolskich spółek giełdowych. Przyjać należy, że wielkopolskie spółki giełdowe nie są próbą reprezentatywna dla populacji przedsiębiorstw działających w ramach województwa wielkopolskiego. Zatem wyniki uzyskane w pracy dotycza tylko analizowanych spółek i należy traktować je jako egzemplifikację poruszanej problematyki. Z tych samych powodów nie dokonywano uogólnień na całą populację spółek notowanych na GPW w Warszawie ${ }^{8}$.

Pomiar dokonań w ramach koncepcji zarządzania przez wartość wymaga zdefiniowania wartości, którą się mierzy. Pojęcie wartości używane w odniesieniu do przedsiębiorstwa jest bowiem niejednoznaczne, a szczegółowe jej definicje różnią się między sobą ${ }^{9}$, co przekłada się także na różne definiowane w literaturze przedmiotu głównego celu działania przedsiębiorstw.

Wartość, do której zwiększania przedsiębiorstwo powinno zmierzać, bywa różnie precyzowana w różnych definicjach ${ }^{10}$. Niektórzy autorzy zalecaja, aby przedsiębiorstwa skupiły się na generowaniu wartości przedsiębiorstwa ${ }^{11}$. Niekiedy definicja precyzuje, że chodzi o rynkową wartość przedsiębiorstwa ${ }^{12}$. Zdaniem autora najtrafniej cel działania przedsiębiorstwa w ramach koncepcji zarządzania przez wartość definiowany jest jako zwiększanie wartości dla właścicieli ${ }^{13}$.

W zrozumieniu problematyki pomiaru rezultatów procesu tworzenia wartości przez przedsiębiorstwa pomóc może systematyka bazująca na schemacie trójfazowego procesu tworzenia wartości ${ }^{14}$, w której generowanie wartości

8 Jeśliby wnioskować na podstawie wyników badań, to stwierdzić można, że z jednej strony badania dotyczą całej populacji wielkopolskich spółek giełdowych z właściwymi wyłączeniami (por. M. Gruszczyński, Empiryczne finanse przedsiębiorstw. Mikroekonometria finansowa, Difin, Warszawa 2012, s. 41). Z kolei jeśliby potraktować badane zbiorowości jako próby pobrane z populacji wszystkich przedsiębiorstw w Polsce, to stwierdzić należy, że badana zbiorowość została dobrana w sposób nieprobabilistyczny (por. S. Nowak, Metodologia badań społecznych, WN PWN, Warszawa 2007, s. 302-303). Podkreślić jednak należy, że wnioskowanie na temat tak rozumianej populacji nie było zamiarem autora. Uzyskane wyniki dotyczą wyłącznie ocenianej zbiorowości i nie będą uogólniane.

${ }^{9}$ Chyba najbardziej szczegółowe omówienie różnych definicji wartości przedsiębiorstwa, nazywanych standardami wartości, znaleźć można w: J. E. Fishman, S. P. Pratt, W. J. Morrison, Standards of Value. Theory and Applications, wyd. 2, John Wiley \& Sons, Hoboken 2013.

${ }^{10}$ Różnice między definicjami celu działania przedsiębiorstwa w ramach koncepcji VBM nie sprowadzaja się jedynie do szczegółowego określenia wartości, która ma być zwiększana. Wskazuje się m.in. na nieadekwatność sformułowania „maksymalizacja” używanego przez wielu autorów. Te zagadnienia zostały omówione przez autora w: J. Nowicki, Zwiększanie wartości dla właścicieli a cel dziatania przedsiębiorstwa w teorii firmy, w: E. Urbańczyk et al. (red.), Metodologiczne aspekty zarzqdzania wartościa przedsiębiorstwa, Zeszyty Naukowe nr 737, Finanse, Rynki Finansowe, Ubezpieczenia nr 56, WNEiZ US, Szczecin 2012, s. 193-210.

${ }^{11}$ Por. np. T. Copeland, T. Koller, J. Murrin, Wycena: mierzenie i ksztattowanie wartości firm, WIG Press, Warszawa 1997, s. 87; A. Szablewski (red.), Strategie wzrostu wartości firmy. Studium przypadków, Poltext, Warszawa 2000, s. 15; P. Szczepankowski, Wycena i zarzadzanie wartościa przedsiębiorstwa, WN PWN, Warszawa 2007, s. 20.

${ }_{12}$ Por. np. A. Jaki, Wycena przedsiębiorstwa, Oficyna Ekonomiczna, Kraków 2006, s. 34.

${ }^{13}$ Por. np. M. Michalski, Zarzqdzanie przez wartość, WIG-Press, Warszawa 2001, s. 23.

${ }_{14}$ Autor przedstawił ją w artykule: J. Nowicki, Systematyka metod pomiaru wartości w ramach zarzadzania wartościq przedsiębiorstwa, „Zeszyty Naukowe Uniwersytetu Szczecińskiego. Finanse, Rynki Finansowe, Ubezpieczenia", Szczecin 2014 (w druku). 
przedsiębiorstwa $\mathrm{w}$ pierwszej i drugiej fazie (budowania i utrzymania wartości) jest warunkiem koniecznym tworzenia wartości, ale to trzecia faza, w której następuje przekazanie wartości właścicielom, jest kluczowa i stanowi dopełnienie procesu kreacji wartości dla właścicieli. Mierniki wartości kreowanej wypracowane w ramach koncepcji VBM ${ }^{15}$ mierzyć mogą zarówno przyrost wartości przedsiębiorstwa (lub wartości kapitału własnego) ${ }^{16}$, jak i przyrost wartości dla właścicieli ${ }^{17}$.

Biorąc pod uwagę powyższe podstawy teoretyczne, w części empirycznej do określenia efektów tworzenia wartości przez wielkopolskie spółki giełdowe posłużono się zarówno zyskiem ekonomicznym (miarą przyrostu wartości przedsiębiorstwa), jak i standaryzowaną wersją miernika CSV (miarą wartości przekazanej właścicielom).

Odpowiedzi na pytanie o to, co właściwie oznacza, że przedsiębiorstwo tworzy wartość, udzielić można na gruncie teorii finansów przedsiębiorstwa. Jedna z podstawowych zasad finansów przedsiębiorstwa mówi, że firma powinna inwestować w aktywa tylko wtedy, gdy oczekuje osiagnięcia stopy zwrotu wyższej niż minimalna wymagana stopa zwrotu ${ }^{18}$. Zasada ta wynika z logiki inwestycyjnej. Skoro istota inwestowania jest bieżące wyrzeczenie dla przyszłych korzyści ${ }^{19}$, to racjonalny inwestor oczekuje zwrotu z kapitału zainwestowanego w jakiekolwiek przedsięwzięcie stosownie do ponoszonego przez siebie ryzyka. Jeśli więc przedsiębiorstwo potraktuje się jak przedsięwzięcie inwestycyjne, to miarą sukcesu będzie stopień, w jakim kapitał właściciela został pomnożony, a punktem odniesienia tego porównania będzie minimalna

15 Abstrahuje się w tym miejscu od pomiaru wartości na dany moment, co jest domeną wyceny przedsiębiorstwa, koncentruje zaś się na pomiarze zmian wartości za dany okres, co jest domena dociekań w ramach pomiaru dokonań.

${ }_{16}$ Wśród miar zmierzających do odpowiedzi na pytanie o przyrost wartości przedsiębiorstwa lub kapitału własnego w danym okresie wymienić można ekonomiczną wartość dodaną (EVA economic value added) i inne rodzaje zysku ekonomicznego, jak również mierniki konkurencyjne w stosunku do EVA, takie jak gotówkowa stopa zwrotu z inwestycji i bazująca na niej gotówkowa wartość dodana (CFROI - cash flow return on investment, CVA - cash value added) czy gotówkowa wartość dodana Weissenriedera i Ottossona (CVA - cash value added). Por. A. Rappaport, op. cit.; G. B. Stewart, The Quest for Value. A Guide for Senior Managers, HarperBusiness, New York 1991, s. 137; A. Ehrbar, EVA - strategia tworzenia wartości przedsiębiorstwa, WIG-Press, Warszawa 2000; B. J. Madden, CFROI ${ }^{\mathrm{TM}}$ Valuation. A Total System Approach to Valuing the Firm, Butterworth Heinemann, Oxford 1999; E. Ottosson, F. Weissenrieder, Cash Value Added - A New Method for Measuring Financial Performance, Working Paper, Study No 1996:1, http:// papers.ssrn.com (dostęp: 27.03.2014).

17 Wśród mierników wartości wytworzonej dla właścicieli (stopnia przekazania wartości właścicielom) wymienić można wartość wytworzoną dla akcjonariuszy (CSV - created shareholder value) czy ekonomiczną wartość dodaną dla właścicieli (SEVA - shareholder economic value added). Por. M. Michalski, Zarzqdzanie..., s. 110; P. Fernandez, Definition of Shareholder Value Creation, SSRN Working Paper, 2001, http://papers.ssrn.com (dostęp: 27.03.2014); P. Fernandez, L. Reinoso, Shareholder Value Creators and Shareholder Value Destroyers in USA. Year 2001, Research Paper nr 485 (dostęp: 27.03.2014).

18 Por. A. Damodaran, Finanse korporacyjne. Teoria i praktyka, wyd. 2, OnePress, Gliwice 2007, s. 39 .

19 Por. J. Hirshleifer, Investment Decisions under Uncertainty - Choice Theoretic Approaches, „The Quarterly Journal of Economics” 74, 1965, nr 4, s. 509. 
wymagana stopa zwrotu. Zatem wartość jest tworzona wtedy, gdy osiagnięta stopa zwrotu przewyższa minimalną wymaganą stopę zwrotu, czyli koszt kapitału. Ilustruje to tabela 1.

Tabela 1

Stopa zwrotu i koszt kapitału a tworzenie wartości

\begin{tabular}{|l|l|}
\hline \multicolumn{1}{|c|}{ Warunek } & \multicolumn{1}{c|}{ Efekt - zmiana wartości } \\
\hline Osiagnięta stopa zwrotu < koszt kapitału & Niszczenie wartości \\
\hline Osiagnięta stopa zwrotu = koszt kapitału & $\begin{array}{l}\text { Zachowanie wartości na niezmienionym } \\
\text { poziomie }\end{array}$ \\
\hline Osiągnięta stopa zwrotu > koszt kapitału & Tworzenie wartości \\
\hline
\end{tabular}

Źródło: opracowanie własne.

Przeniesienie powyższych rozważań na grunt teorii przedsiębiorstwa pozwala stwierdzić, że osiaganie stopy zwrotu przewyższającej koszt kapitału już w tradycyjnej (neoklasycznej) teorii przedsiębiorstwa oznaczało generowanie zysku czystego (nadzwyczajnego) ${ }^{20}$. Dlatego też właśnie do koncepcji zysku czystego nawiązują współczesne mierniki wartości kreowanej, takie jak ekonomiczna wartość dodana czy inne odmiany zysku ekonomicznego. W związku z powyższym interesujace wydają się teorie wyjaśniające pochodzenie zysków czystych. Szczególnie istotne wydają się tutaj dwie grupy poglądów, których prekursorami byli odpowiednio F. Knight i J. Schumpeter.

Według F. Knighta zysk czysty jest zarobkiem z tytułu niepewności. Oparł on swoje rozważania na wprowadzonym przez J. H. von Thuenena rozróżnieniu pomiędzy ryzykiem i niepewnością ${ }^{21}$. Jeśli mierzalną niepewność, czyli ryzyko da się za pomoca rachunku prawdopodobieństwa skwantyfikować, to można ją za pomocą asekuracji przenieść na inne podmioty. Takie ryzyko staje się wtedy składnikiem kosztów przedsiębiorstwa. Istnieją jednak rodzaje niepewności, których nie da się zmierzyć, ponieważ związane są z wydarzeniami bez precedensu lub takimi, które w przeszłości zachodziły zbyt rzadko, aby można było określić rozkład prawdopodobieństwa. Jedynie taka niepewność, wynikająca z wzięcia na siebie całkowitej ostatecznej odpowiedzialności jest, zdaniem F. Knighta, źródłem czystego zysku.

${ }^{20}$ Zysk w tradycyjnej teorii przedsiębiorstwa obejmuje dwie składowe: zysk normalny odpowiadający kosztowi alternatywnemu (kosztowi utraconych możliwości, innego zastosowania zasobów właściciela) oraz zysk nadzwyczajny (czysty), który stanowi residuum po pokryciu wszystkich kosztów rzeczywistych i alternatywnych. Por. M. Gorynia, Zachowania przedsiębiorstw w okresie transformacji. Mikroekonomia przejścia, Wyd. AEP, Poznań 1998, s. 17.

${ }^{21}$ J. H. von Thuenen uważał wynagrodzenie przedsiębiorcy za przychód otrzymywany w zamian za wzięcie na siebie tych rodzajów ryzyka, których nie chce pokryć żadne towarzystwo asekuracyjne, dlatego że są nieprzewidywalne. Por. M. Blaug, Teoria ekonomii. Ujęcie retrospektywne, WN PWN, Warszawa 2000, s. 472. 
Z kolei według J. Schumpetera zysk czysty jest zapłatą za innowacje. Sa one nie tylko źródłem osiągania zysku czystego, ale także motorem zmian $\mathrm{w}$ gospodarce ${ }^{22}$. Zmiany innowacyjne J. Schumpeter podzielił na trzy fazy: pomysł (invention), wprowadzenie innowacji (innovation) oraz dyfuzję (difusion), tj. upowszechnienie innowacji za sprawą naśladowców. W ujęciu J. Schumpetera bardzo istotna rolę w przeprowadzeniu zmian innowacyjnych odgrywa przedsiębiorca ${ }^{23}$, który wybiera pomysł umożliwiający osiaganie zysków czystych, dzięki zdolnościom organizacyjnym uczestniczy w przetworzeniu pomysłu w efekt końcowy, znajdujacc źródła finansowania innowacji. Rola przedsiębiorcy jest tak ważna, ponieważ dopiero po uplasowaniu innowacji na rynku może ona przynieść zyski czyste. Te z kolei przyciagaja naśladowców, co prowadzi do dyfuzji innowacji i zanikania zysków czystych ${ }^{24}$. Stąd rzeczywistym źródłem wzrostu gospodarczego w skali makroekonomicznej, a zysków czystych (czyli tworzenia wartości) w skali mikroekonomicznej jest działalność innowacyjnego przedsiębiorcy, a nie masowa aktywność naśladowców ${ }^{25}$.

Przytoczone dwie grupy poglądów dotyczą istoty kreacji wartości w przedsiębiorstwach, ponieważ omawiaja przyczyny tego procesu, stanowiąc jednocześnie interesująca konstrukcję dla interpretacji rezultatów tworzenia wartości w badanych przedsiębiorstwach.

\section{METODYKA BADANIA}

W części empirycznej pracy badaniu poddano spółki akcyjne mające siedzibę na terenie województwa wielkopolskiego, których akcje notowane są na Giełdzie Papierów Wartościowych w Warszawie ${ }^{26}$. Celem badania była odpowiedź na pytanie, czy spółki te tworzyły wartość, czy przekazywały wartość właścicielom, co determinowało zmiany wartości wytworzonej w poszczególnych latach oraz czy w grupie analizowanych spółek efekt kreacji wartości był skorelowany z przekazywaniem wartości właścicielom. Do pomiaru efektu tworzenia wartości wykorzystano zysk ekonomiczny (EP - economic profit) oraz względny zysk ekonomiczny (REP - relative economic profit), natomiast aby zmierzyć efekt przekazania wartości właścicielom wykorzystano standaryzowany wskaźnik wartości wytworzonej dla akcjonariuszy (CSVspread created shareholder value spread). Do oceny zależności między obiema miarami wykorzystano współczynnik korelacji liniowej Pearsona, natomiast oceny

${ }^{22}$ Por. J. Schumpeter, Teoria rozwoju gospodarczego, PWN, Warszawa 1960, s. 204-250. Por. także M. Blaug, op. cit., s. 475; M. Gorynia, op. cit., s. 17.

${ }^{23}$ Por. J. Schumpeter, op. cit., s. 129-150.

${ }_{24}$ Por. T. Gruszecki, Wspótczesne teorie przedsiębiorstwa, WN PWN, Warszawa 2002, s. 196.

${ }_{25}$ Por. H. Landreth, D. C. Colander, Historia myśli ekonomicznej, WN PWN, Warszawa 2005, s. 401; K. Sobiech, B. Woźniak, Inne nurty wspótczesnej ekonomii alternatywnej, w: M. Ratajczak (red.), Współczesne teorie ekonomiczne, Wyd. AEP, Poznań 2005, s. 164.

26 Według stanu z 24.10.2014 r. 
determinant zmian wytworzonej wartości dokonano, opierając się na dekompozycji zysku ekonomicznego za pomocą metody kolejnych podstawień, która jest jedna z deterministycznych metod analizy przyczynowej w analizie ekonomicznej przedsiębiorstwa.

Zakres czasowy badania obejmuje lata 2010-2013, jednak do obliczenia współczynników beta wykorzystano notowania giełdowe od pierwszego notowania akcji poszczególnych spółek. Na potrzeby badania korelacji pomiędzy miernikami REP i CSVspread dane dla każdego roku z okresu 2010-2013 potraktowano jako dane przekrojowe.

Dane wykorzystane w badaniu pochodzą z różnych źródeł. Notowania akcji spółek pozyskano z bazy danych Stooq.pl. Do obliczeń wykorzystano przekształcone ceny akcji spółek giełdowych, uwzględniające dywidendy, splity, prawa poboru i inne zdarzenia dotyczace akcji. W badaniu wykorzystano tygodniowe notowania akcji. Zakres czasowy wykorzystanych danych obejmuje okres od pierwszego notowania każdej akcji do końca grudnia $2013 \mathrm{r}$. Na podstawie tych danych obliczono komponenty miar użytych w badaniu empirycznym (EP, REP i CSVspread), tj. współczynniki beta wykorzystane w szacowaniu kosztu kapitału własnego oraz całkowita stopę zwrotu dla akcjonariuszy (TSR - total shareholder return), będąca składową CSVspread.

Z bazy danych Notoria pozyskano jednostkowe roczne raporty finansowe wielkopolskich spółek giełdowych notowanych na głównym parkiecie GPW w Warszawie (wg stanu na 24.10.2014 r. dane finansowe wielu spółek za lata 2012-2013 oznaczone sa jako przewidywane). W obliczeniach wykorzystano oprogramowanie Statistica oraz Excel wraz z procedurami napisanymi w języku programowania Visual Basic for Applications.

Postępowanie badawcze objęło cztery etapy:

1) pomiar efektów budowania wartości przez wielkopolskie spółki giełdowe w latach 2010-2013 na podstawie zysku ekonomicznego i względnego zysku ekonomicznego;

2) pomiar efektów przekazania wartości właścicielom przez wielkopolskie spółki giełdowe w latach 2010-2013 z wykorzystaniem miernika CSVspread;

3) analiza związku pomiędzy budowaniem a przekazaniem wartości w wielkopolskich spółkach giełdowych w latach 2010-2014 za pomocą miary korelacji;

4) analiza determinant zmian wartości przedsiębiorstwa mierzonych za pomocą zysku ekonomicznego w badanym okresie metodą kolejnych podstawień.

W pierwszym etapie dla każdej spółki biorącej udział w badaniu obliczono względny zysk ekonomiczny (REP), zgodnie z formuła:

gdzie:

$$
\mathrm{REP}_{\mathrm{t}}=\mathrm{EP}_{\mathrm{t}} / \mathrm{E}_{\text {begt }} \text {, }
$$

$\mathrm{REP}_{\mathrm{t}}$ - względny zysk ekonomiczny w okresie $t$,

$\mathrm{EP}_{\mathrm{t}}$ - zysk ekonomiczny w okresie $t$,

$\mathrm{E}_{\text {begt }} \quad-$ księgowa wartość kapitału własnego na początku okresu $t$. 
Zysk ekonomiczny (EP) obliczono według wzoru:

gdzie:

$$
\mathrm{EP}_{\mathrm{t}}=\mathrm{NI}_{\mathrm{t}}-\mathrm{k}_{\mathrm{t}} \times \mathrm{E}_{\text {begt }},
$$

$\mathrm{NI}_{\mathrm{t}}$ - zysk netto w okresie $t$,

$\mathrm{k}_{\mathrm{t}} \quad$ - koszt kapitału własnego w okresie $t$,

pozostałe oznaczenia jak we wzorze (1).

W kalkulacji zysku ekonomicznego używa się różnych wzorów. Formuła bazująca na zysku operacyjnym po opodatkowaniu (ze średnim ważonym kosztem kapitału oraz kapitałem zainwestowanym) wydaje się najpopularniejsza głównie za sprawa częstego stosowania w obliczeniach ekonomicznej wartości dodanej, która jest rodzajem zysku ekonomicznego ${ }^{27}$. Taka formuła umożliwia ocenę działalności, abstrahując od kwestii nieoperacyjnych i nadzwyczajnych, co jest przydatne w budowie programów motywacyjnych dla menedżerów. Taka formuła pozwala także obliczyć zysk ekonomiczny w odniesieniu do filii bądź dywizji przedsiębiorstwa ${ }^{28}$. W niniejszym badaniu zdecydowano się jednak na formułę tradycyjna ${ }^{29}$, bazująca na zysku netto (z kosztem kapitału własnego i kapitałem własnym), głównie dlatego, że ujmuje ona wszystkie zdarzenia wpływające na wyniki finansowe, a nie tylko te operacyjne. Ponadto na taki wybór wpływ miał także zakres danych ujawnianych w bazie danych Notoria $^{30}$. We wzorze (2) wykorzystano także księgową wartość kapitału własnego ${ }^{31}$. Dane jednej z analizowanych spółek (Komputronik) odnoszą się do lat obrotowych kończących się w ostatnim dniu marca. Rok obrotowy pozostałych spółek pokrywał się z kalendarzowym.

Koszt kapitału własnego oszacowano, opierając się na modelu wyceny aktywów kapitałowych (CAPM - capital asset pricing model):

gdzie:

$$
\mathrm{k}_{\mathrm{t}}=\mathrm{r}_{\mathrm{f}}+B\left(\mathrm{r}_{\mathrm{m}}-\mathrm{r}_{\mathrm{f}}\right),
$$

$\mathrm{k}_{\mathrm{t}} \quad-$ koszt kapitału własnego w okresie $t$,

$\mathrm{r}_{\mathrm{f}} \quad$ - stopa zwrotu wolna od ryzyka,

B - współczynnik beta,

$\mathrm{r}_{\mathrm{m}}-\mathrm{r}_{\mathrm{f}}-$ premia za ryzyko rynkowe.

${ }^{27}$ Por. np. S. D. Young, S. F. O’Byrne, EVA and Value-Based Management. A Practical Guide to Implementation, McGraw-Hill, 2001, s. 35; G. B. Stewart, The Quest..., s. 136-150.

${ }_{28}$ Por. S. Gillan, Corporate Governance, EVA and Shareholder Value, An Interview with Joel Stern, „Journal of Applied Corporate Finance” 16, 2004, nr 2-3 (Spring/Summer).

${ }^{29}$ Por. A. Cwynar, Zysk ekonomiczny jako narzędzie informacyjno-sygnalizacyjne $w$ systemie VBM, w: A. Cwynar, P. Dżurak (red.), Systemy VBM i zysk ekonomiczny, Poltext, Warszawa 2010, s. $73-74$.

${ }^{30} \mathrm{~W}$ sprawozdaniach finansowych spółek giełdowych dostarczanych przez firmę Notoria brak szczegółowego podziału zobowiązań krótkoterminowych, co uniemożliwia właściwą kalkulację kapitału obcego oprocentowanego, a w konsekwencji - kapitału zainwestowanego. Dlatego stosowanie formuły opartej na zysku operacyjnym po opodatkowaniu wymagałoby przyjęcia arbitralnych założeń co do natury zobowiązań krótkoterminowych. Stosowanie wzoru (2) nie wymaga takich posunięć, dlatego wydaje się korzystniejszym rozwiązaniem.

${ }^{31}$ Zgodnie z zaleceniami zawartymi w: G. B. Stewart, Accounting is Broken. Here's How to Fix It. A Radical Manifesto, „EVAluation - Stern Stewart Research”, vol. 5, issue 1, September 2002, http://www.sternstewart.com/content/evaluation/info/092002.pdf, s. 9 (dostęp: 19.06.2004). 
Za stopę zwrotu wolną od ryzyka zgodnie z zaleceniami płynącymi z literatury przedmiotu ${ }^{32}$, przyjęto średnią stopę rentowności pięcioletnich obligacji skarbowych dla odpowiednich lat ${ }^{33}$. Premię za ryzyko rynkowe przyjęto na podstawie oszacowań A. Damodarana ${ }^{34}$.

Współczynnik beta został oszacowany oddzielnie dla każdej spółki. Podstawą obliczeń współczynnika beta były tygodniowe logarytmiczne stopy zwrotu obliczone na podstawie notowań spółek giełdowych pobranych z bazy danych Stooq.pl (notowań przekształconych, uwzględniających zdarzenia na akcjach, takie jak dywidendy, splity, prawa poboru itp.). Dla każdej spółki w każdym z badanych lat betę obliczono na podstawie tygodniowych stóp zwrotu za okres od pierwszego notowania do końca danego roku obrotowego. Rozwiąanie takie przyjęto dla zachowania porównywalności mierników REP i CSVspread. Współczynnik beta oszacowano zgodnie z następującym wzorem:

gdzie:

$$
B=\operatorname{cov}\left(r_{i}, r_{m}\right) / \operatorname{var}\left(r_{m}\right),
$$

$\operatorname{cov}\left(\mathrm{r}_{\mathrm{i}}, \mathrm{r}_{\mathrm{m}}\right)$ - kowariancja stóp zwrotu $\mathrm{z}$ danej akcji oraz z portfela rynkowego, $\operatorname{var}\left(\mathrm{r}_{\mathrm{m}}\right)$ - wariancja stóp zwrotu z portfela rynkowego.

Stopy zwrotu z portfela rynkowego obliczono na podstawie notowań indeksu WIG.

W drugim etapie dla każdej spółki biorącej udział w badaniu obliczono miernik CSVspread, zgodnie z formuła:

gdzie:

$$
\text { CSVspread }=\mathrm{TSR}_{\mathrm{t}}-\mathrm{k}_{\mathrm{t}},
$$

$\mathrm{TSR}_{\mathrm{t}}$ - całkowity zwrot dla akcjonariuszy w okresie $t$ (total shareholder return), $\mathrm{k}_{\mathrm{t}} \quad$ - koszt kapitału własnego $\mathrm{w}$ okresie $t$, oszacowany jak opisano powyżej.

Miernik TSR w poszczególnych okresach obliczono na podstawie notowań z końca roku obrotowego (notowań przekształconych, uwzględniających zdarzenia na akcjach, takie jak dywidendy, splity, prawa poboru itp.), jako roczna logarytmiczną stopę zwrotu.

W trzecim etapie przeanalizowano korelację między miernikami REP a CSVspread za pomoca współczynnika korelacji liniowej Pearsona. W analizie korelacji dokonano badań przekrojowych dla każdego z czterech lat osobno. W badaniu użyto wskaźników relatywnych, aby umożliwić porównania między przedsiębiorstwami różniącymi się wielkością.

Etap czwarty badania zmierzał do wskazania przyczyn zmian wartości przedsiębiorstwa w wielkopolskich spółkach giełdowych. W tym celu dokonano dekompozycji zysku ekonomicznego zgodnie ze wzorem ${ }^{35}$ :

${ }^{32}$ Por. E. F. Brigham, L. C. Gapenski, op. cit., t. 1, s. 246; A. Damodaran, Finanse..., s. 321.

${ }^{33}$ MAKROscope. Polish Economy and Financial Markets, (2014, 2012, 2011, 2010), Bank Zachodni WBK, July-August 2014, December 2012, December 2011, December 2010, http://skarb. bzwbk.pl/english/economic-analysis/macroscope/archiwum.html (dostęp 16.07.2014).

${ }^{34}$ A. Damodaran, Data Sets, http://people.stern.nyu.edu/adamodar/New_Home_Page/data. html (dostęp: czerwiec 2014).

${ }^{35}$ Bardziej szczegółowa dekompozycja zysku ekonomicznego nie była możliwa ze względu na niski stopień szczegółowości i jakość dostępnych danych. 
gdzie:

$$
\mathrm{EP}_{\mathrm{t}}=\mathrm{GI}_{\mathrm{t}}\left(1-\mathrm{T}_{\mathrm{t}}\right)-\mathrm{k}_{\mathrm{t}} \times \mathrm{E}_{\text {begt }},
$$

GI $_{t}$ - zysk brutto w okresie $t$,

$\mathrm{T}_{\mathrm{t}}$ - efektywna stopa podatku dochodowego w okresie $t$, obliczona jako relacja podatku dochodowego i innych obciążeń wyniku finansowego do zysku brutto,

pozostałe oznaczenia jak we wzorze (2).

Następnie zbadano wpływ poszczególnych zmiennych na zmiany zysku ekonomicznego w poszczególnych latach za pomocą metody kolejnych podstawień $^{36}$, przyjmując kolejność podstawiania zmiennych zgodną z porządkiem ich pojawiania się we wzorze (6).

Badaniu poddano wielkopolskie spółki giełdowe. Grupa ta według stanu z 24 października 2014 r. obejmuje 34 spółki, w szczególności ${ }^{37}$ : Amica Wronki SA (AMC), Arctic Paper SA (ATC), Atrem SA (ATR), Briju SA (BRI), BSC Drukarnia Opakowań SA (BSC), Colian Holding SA (COL), Czerwona Torebka SA (CZT), Decora SA (DCR), Delko SA (DEL), DGA SA (DGA), Grupa DUON SA (DUO), Enea SA (ENA), Eurocash SA (EUR), Groclin SA (GCN), INC SA (INC), Izolacja-Jarocin SA (IZO), Komputronik SA (KOM), Lubawa SA (LBW), Lena Lighting SA (LEN), One-2-One SA (O2O), PBG SA w upadłości układowej (PBG), PBO Anioła SA w upadłości układowej (PBO), PC Guard SA (PCG), Pozbud T\&R SA (POZ), Powszechne Towarzystwo Inwestycyjne SA (PTI), Skystone Capital SA (SKC), Solar Company SA (SOL), Tell SA (TEL), Pani Teresa-Medica SA (TER), Talex SA (TLX), Torpol SA (TOR), TESGAS SA (TSG), WISTIL SA (WST), Zespół Elektrowni Pątnów-Adamów-Konin SA (ZEP). Z materiału badawczego wyłączono niektóre spółki oraz niektóre obserwacje ze względu na niewystarczajacy okres notowań giełdowych. Aby zapewnić wiarygodne szacunki współczynnika beta, przyjęto zasadę, że spółka bioracca udział w badaniu w danym roku musi być notowana przez co najmniej rok. Na tej podstawie z analizy wyłączono spółkę Torpol, jak również obserwacje z lat 2010-2011 dla BRI, BSC i PBO oraz obserwacje z lat 2010-2012 dla CZT, SOL i ZEP.

\section{WYNIKI BADAŃ ORAZ ICH INTERPRETACJA}

W tabeli 2 przedstawiono zyski ekonomiczne, względne zyski ekonomiczne i wielkości CSVspread wygenerowane przez wielkopolskie spółki giełdowe w latach 2010-2013.

\footnotetext{
${ }^{36}$ Por. T. Waśniewski, Analiza finansowa w przedsiębiorstwie, Fundacja Rozwoju Rachunkowości w Polsce, Warszawa 1997, s. 23-26; A. Ćwiąkała-Małys, W. Nowak, Zarys metodologiczny analizy finansowej, Wyd. UWr, Wrocław 2005, s. 26-34.

37 W nawiasach podano skróty nazw spółek, którymi dla uproszczenia posługiwano się w dalszej części artykułu.
} 
Analiza danych zawartych w tabeli 2 pozwala stwierdzić, że w każdym analizowanym roku spółki z dodatnim zyskiem ekonomicznym były w mniejszości (dodatni zysk ekonomiczny odnotowało 12 z 26 spółek w 2010 r., 8 z 29 spółek - w 2011, 11 z 32 spółek - w 2012 oraz 14 z 33 spółek - w 2013). Oznacza to, że więcej wielkopolskich spółek giełdowych marnotrawiło wartość, niż ją pomnażało.

Zważywszy na różną skalę działalności poszczególnych spółek i różna wielkość zaangażowanego w nie kapitału, porównań między nimi należy dokonywać na podstawie względnego zysku ekonomicznego. Analiza wyników pod tym względem potwierdza wcześniejszą konstatację, że wielkopolskie spółki giełdowe w badanym okresie raczej zmniejszały wartość przedsiębiorstwa (zarówno średnia, jak i mediana względnego zysku ekonomicznego dla grupy wielkopolskich spółek giełdowych są ujemne i ulegają pogorszeniu w latach 2010-2012 oraz poprawie w 2013 r.).

Najlepiej w rankingu wielkopolskich spółek giełdowych pod względem względnego zysku ekonomicznego wypada spółka PTI, która trzykrotnie zajęła pierwsze miejsce i jeden raz drugie (w 2011 r.). Jest to spółka stabilnie budujacca wartość. Do podmiotów utrzymujących się w całym badanym okresie w czołówce rankingu zaliczyć można spółki EUR, TEL i TER. Natomiast w końcówce rankingu w całym badanym okresie znaleźć można O2O (dziewiąte miejsce w 2013 r. nie jest miarodajne, ponieważ wynika z niedoskonałości miary, jaką jest REP, ujawniającej się w sytuacji oceny spółki osiagającej stratę netto i posiadającej ujemny kapitał własny ${ }^{38}$ ). Trudności spółek PBO i PBG, które skutkowały ogłoszeniem ich upadłości z możliwością zawarcia układu, widoczne są także w pogarszających się poziomach względnego zysku ekonomicznego oraz pozycji w rankingu ${ }^{39}$.

Ponieważ w ramach systemów VBM podkreśla się konieczność poprawy wyników pod względem tworzenia wartości ${ }^{40}$, przeanalizowano pod tym kątem wyniki uzyskane przez wielkopolskie spółki giełdowe. W badanym okresie sześć spółek systematycznie poprawiało się pod względem budowania wartości, pięć spółek systematycznie pogarszało poziom generowanego zysku ekonomicznego, natomiast w przypadku pozostałych spółek brak jest wyraźnej tendencji ${ }^{41}$.

${ }^{38}$ Iloraz dwóch ujemnych liczb daje liczbę dodatnią. Wspomniana niedoskonałość dotyczy w badanej zbiorowości spółek O2O i PBG w 2013 r.

${ }^{39}$ Choć akurat na pozycję w rankingu spółki PBG wpływ miała także opisana powyżej niedoskonałość miernika REP w ocenie podmiotów z ujemnym kapitałem własnym. Sąd ogłosił upadłość PBG z możliwością zawarcia układu w 2012 r., a w przypadku PBO - w 2014 r.

${ }^{40} \mathrm{Na}$ przykład autorzy ekonomicznej wartości dodanej (EVA), będącej w istocie skorygowanym zyskiem ekonomicznym, podkreślają konieczność oparcia systemu motywacyjnego na przyrostach EVA, a nie na jej bezwzględnej wartości. Por. A. Ehrbar, op. cit., s. 88.

${ }^{41}$ Nie przedstawiono analizy uzyskanych wyników w podziale na sektory działalności głównie z uwagi na znaczne zróżnicowanie wielkopolskich spółek giełdowych pod tym względem, co prowadzi do tego, że wiele sektorów (8 z 16) ma wśród wielkopolskich spółek giełdowych tylko jednego przedstawiciela. 


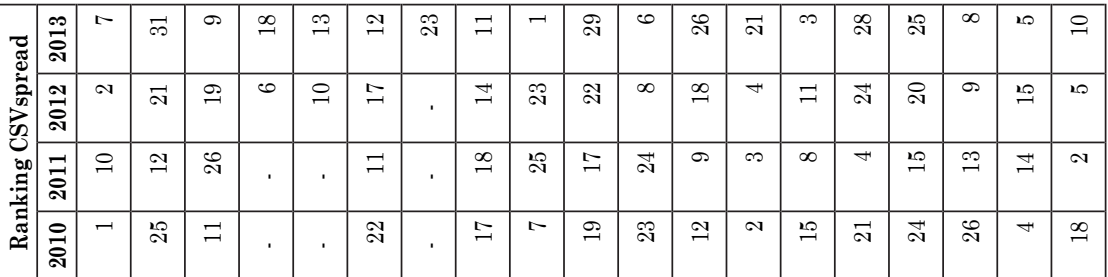

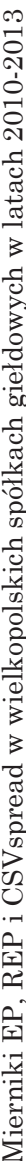

承

20 ลे

焉

을

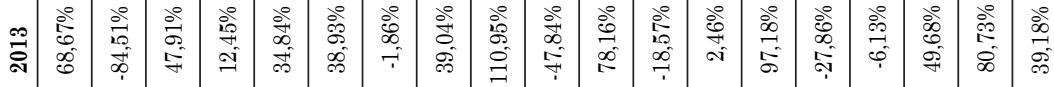

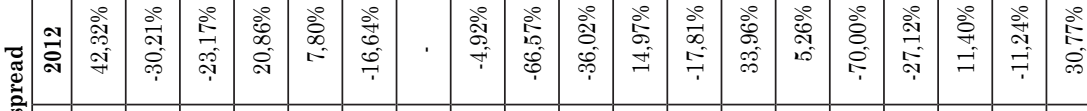

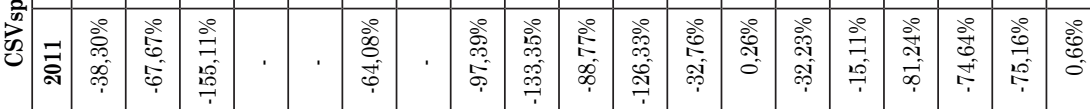

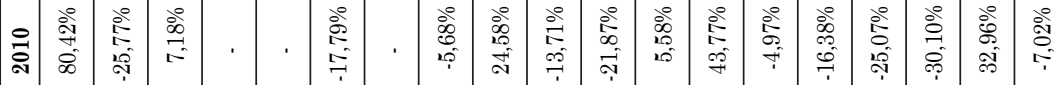

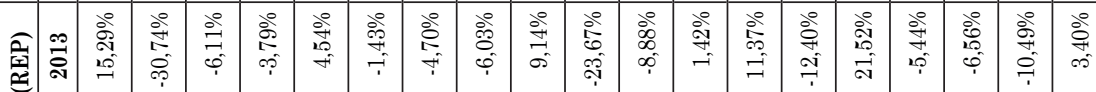

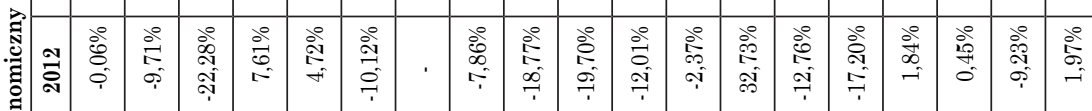

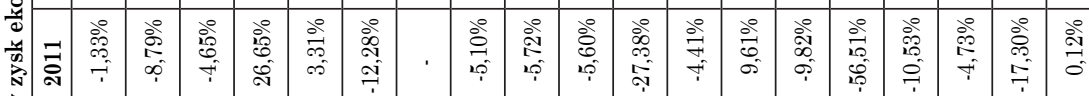

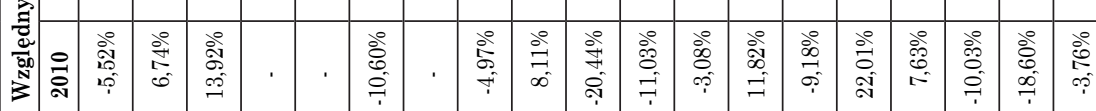

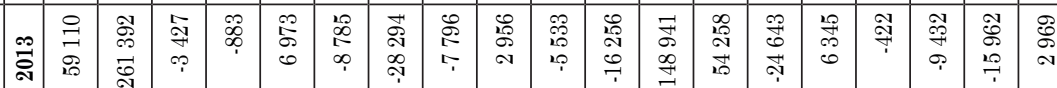

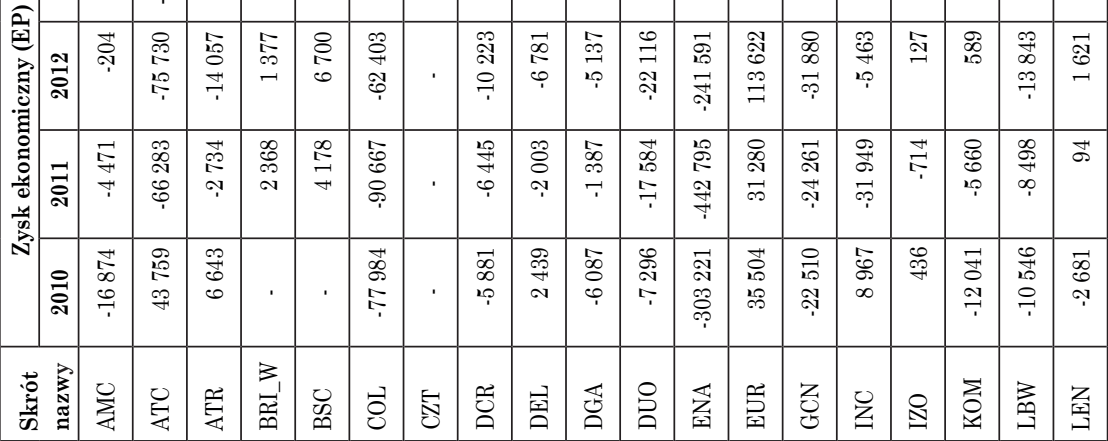




\begin{tabular}{|c|c|c|c|c|c|c|c|c|c|c|c|c|c|c|c|c|c|c|}
\hline$\stackrel{0}{\sim}$ & ๙ & 득 & ลิ & $\underset{\sim}{ }$ & $\stackrel{9}{9}$ & œ & \& & $\stackrel{10}{7}$ & \& & 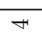 & 忍 & N & $\stackrel{\sim}{\Delta}$ & & & & & \\
\hline ๑ి & \& & $\stackrel{\infty}{\sim}$ & $\infty$ & 고 & $r$ & $\overleftarrow{\mathrm{N}}$ & 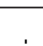 & $\stackrel{\varphi}{\prime}$ & $\stackrel{9}{\sim}$ & $\stackrel{20}{N}$ & $\stackrel{\mathscr{N}}{ }$ & 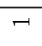 & & & & & & \\
\hline $\overrightarrow{\mathrm{N}}$ & $\stackrel{\sim}{\sim}$ & & ลి & $\stackrel{\varphi}{\sim}$ & $\neg$ & ণ্ & . & 0 & 10 & $r$ & $\stackrel{\sim}{\sim}$ & $\overline{\mathrm{N}}$ & & & & & & \\
\hline$\overline{\mathrm{N}}$ & $\stackrel{\mathscr{L}}{ }$ & & 20 & $\sigma$ & $\infty$ & 0 & t. & $\infty$ & 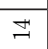 & $\stackrel{\oplus}{\sim}$ & $\stackrel{-}{\sim}$ & จ & & & & & & \\
\hline$\sigma$ & \& & 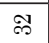 & $\mathscr{\sim}$ & $\stackrel{20}{\sim}$ & 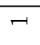 & ๓̊ & $\stackrel{\rho}{\sim}$ & 0 & 10 & $\infty$ & 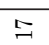 & 10 & $\vec{J}$ & & & & & \\
\hline$\vec{m}$ & ๑) & $\mathscr{\varphi}$ & ন & $\stackrel{20}{9}$ & -1 & & 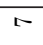 & $\infty$ & 10 & ন্ & \& & ลิ & $\stackrel{\sim}{\circ}$ & & & & & \\
\hline \&্ & $\stackrel{9}{9}$ & $\stackrel{\varphi}{\prime}$ & $\exists$ & $\sim$ & N & . & . & H & 10 & $\vec{\lambda}$ & $\sigma$ & $\mathcal{I}$ & & & & & & \\
\hline $\mathscr{\sim}$ & 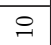 & & $\stackrel{m}{9}$ & 0 & -1 & & . & $\exists$ & I & $\stackrel{\varphi}{\circ}$ & $\infty$ & $\stackrel{19}{\text { S }}$ & & & & & & \\
\hline $\begin{array}{l}\stackrel{\circ}{\stackrel{\circ}{\rightleftarrows}} \\
\text { eी } \\
\text { of }\end{array}$ & 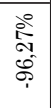 & 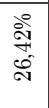 & $\begin{array}{l}\text { ลें } \\
\text { जे } \\
\text { ळ. }\end{array}$ & $\begin{array}{l}\text { वे } \\
\text { o } \\
\text { ô } \\
\text { co }\end{array}$ & $\begin{array}{l}\mathrm{D}^{\circ} \\
\text { i⿱ } \\
\sigma^{\circ}\end{array}$ & $\begin{array}{l}\text { बें } \\
\text {. } \\
0 \\
\stackrel{0}{1}\end{array}$ & $\begin{array}{l}\text { के } \\
\text { जे } \\
\text { फे }\end{array}$ & 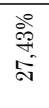 & 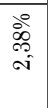 & $\begin{array}{l}\stackrel{0}{ } \\
\infty \\
\infty \\
\delta^{\circ}\end{array}$ & 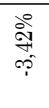 & 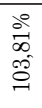 & 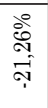 & 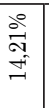 & 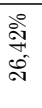 & $\begin{array}{l}\text { बें } \\
\text { ठे } \\
\infty \\
\stackrel{0}{1}\end{array}$ & 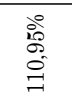 & $\begin{array}{l}\text { 유 } \\
\text { ర․ } \\
\text { O- }\end{array}$ \\
\hline 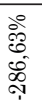 & 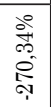 & 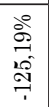 & 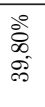 & 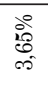 & 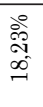 & 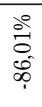 & . & $\begin{array}{l}\text { 空 } \\
\text { if } \\
\text { if }\end{array}$ & $\begin{array}{l}\text { @े } \\
\infty \\
0^{\circ}\end{array}$ & 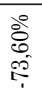 & $\begin{array}{l}\text { ڤे̀ } \\
\text { ठ̀. } \\
\text { ț }\end{array}$ & $\begin{array}{l}\text { ठें } \\
\text { ठ } \\
50\end{array}$ & & 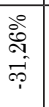 & $\begin{array}{l}\text { 今े } \\
\text { îे } \\
\text { ô } \\
\text { ?े }\end{array}$ & 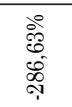 & $\begin{array}{l}80 \\
8 \\
5 \\
5\end{array}$ & $\begin{array}{l}10 \\
0 \\
2 \\
0 \\
0\end{array}$ \\
\hline 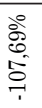 & $\begin{array}{l}\stackrel{0}{0} \\
\infty \\
\circ \\
\stackrel{7}{7}\end{array}$ & & $\begin{array}{l}0 \\
0 \\
0 \\
\stackrel{0}{0} \\
?\end{array}$ & 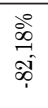 & 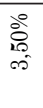 & 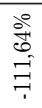 & . & 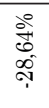 & 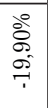 & $\begin{array}{l}\text { 今े } \\
\text { जे } \\
\text { ô } \\
\text { op }\end{array}$ & 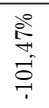 & 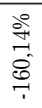 & & 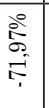 & 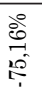 & $\begin{array}{l}\text { ओे } \\
\stackrel{1}{0} \\
\stackrel{0}{1}\end{array}$ & 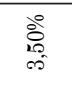 & 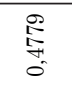 \\
\hline $\begin{array}{l}\text { 今े } \\
\text { Nิ } \\
\text { ôे }\end{array}$ & $\begin{array}{l}0 \\
10 \\
10 \\
10 \\
10\end{array}$ & & $\begin{array}{l}\text { 吕 } \\
\text { 学 }\end{array}$ & 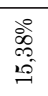 & 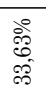 & 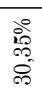 & . & 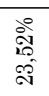 & 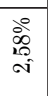 & $\begin{array}{l}\text { के } \\
\text { के } \\
\sigma^{\circ}\end{array}$ & 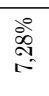 & $\begin{array}{l}\stackrel{\circ}{\stackrel{े}{+}} \\
\stackrel{+}{\rightarrow}\end{array}$ & & 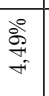 & 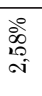 & 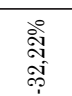 & $\begin{array}{l}\text { 今े } \\
\text { ฟे } \\
\stackrel{\infty}{\circ}\end{array}$ & 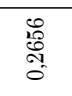 \\
\hline 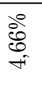 & 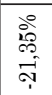 & 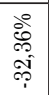 & $\begin{array}{l}\infty \\
\infty \\
\infty \\
\sigma^{\circ}\end{array}$ & 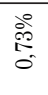 & 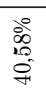 & $\begin{array}{l}\text { 8ें } \\
\text { के } \\
\vec{\sigma}\end{array}$ & 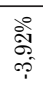 & $\begin{array}{l}\text { \&े } \\
\stackrel{\circ}{\circ} \\
\sigma_{1}\end{array}$ & $\begin{array}{l}\text { @े } \\
\ddot{0} \\
\stackrel{-}{0}\end{array}$ & 鿖 & 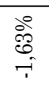 & 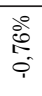 & $\begin{array}{l}\text { 今े } \\
\text { ì. } \\
\text { : }\end{array}$ & 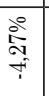 & 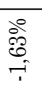 & $\begin{array}{l}\dot{0} \\
\dot{b} \\
\dot{\sigma}\end{array}$ & 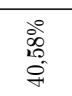 & $\begin{array}{l}0 \\
\stackrel{7}{\lambda} \\
o \\
o\end{array}$ \\
\hline $\begin{array}{l}\text { 总 } \\
\text { 点 } \\
\text { o }\end{array}$ & 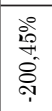 & 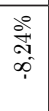 & $\begin{array}{l}\text { वे } \\
\text { î̀ } \\
\text { जै }\end{array}$ & 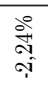 & 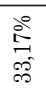 & ' & $\begin{array}{l}\stackrel{\circ}{\circ} \\
\stackrel{-}{\circ}\end{array}$ & 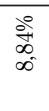 & $\begin{array}{c}0 \\
\vdots 0 \\
0 \\
0\end{array}$ & 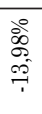 & 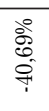 & 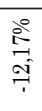 & $\begin{array}{l}\stackrel{0}{\circ} \\
\Rightarrow \\
\Rightarrow\end{array}$ & 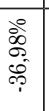 & $\begin{array}{l}\text { Oे } \\
\text { Ni } \\
\text { of } \\
\text { i. }\end{array}$ & 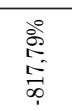 & 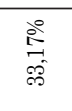 & $\begin{array}{l}\overrightarrow{\mathrm{o}} \\
\stackrel{+}{\rightarrow} \\
\overrightarrow{7}\end{array}$ \\
\hline $\begin{array}{l}\text { ¿े } \\
\text { के } \\
\text { of } \\
\text { of }\end{array}$ & 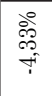 & 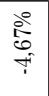 & 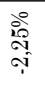 & 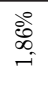 & 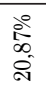 & & . & $\begin{array}{l}\text { ঐे } \\
\text { ఫै } \\
\infty\end{array}$ & 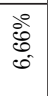 & 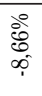 & 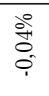 & 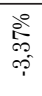 & 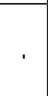 & 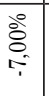 & $\begin{array}{l}\text { ì } \\
\text { i⿱ } \\
+i\end{array}$ & $\begin{array}{l}\text { oे } \\
\text { o. } \\
\text { ô } \\
\text { o. }\end{array}$ & $\begin{array}{l}\text { ¿े } \\
18 \\
80 \\
\text { o }\end{array}$ & $\begin{array}{l}\text { iv } \\
\text { Iิ } \\
\text { ồ } \\
\text { ô }\end{array}$ \\
\hline $\begin{array}{l}\stackrel{\circ}{\circ} \\
\text { ơ } \\
\text { oे }\end{array}$ & $\begin{array}{l}0 \\
\infty \\
\infty \\
\infty \\
+\end{array}$ & . & ठें & $\begin{array}{l}\stackrel{\circ}{\circ} \\
\exists\end{array}$ & $\begin{array}{l}\text { ¿̊̊ } \\
\text { م. } \\
\text { â }\end{array}$ & & . & 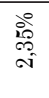 & $\stackrel{\circ}{\circ}$ & $\begin{array}{l}\text { वे } \\
\infty^{\circ} \\
\overbrace{i}^{\circ}\end{array}$ & $\begin{array}{l}\text { 今े } \\
\text { जे } \\
\text { - }\end{array}$ & $\begin{array}{l}\text { ১े } \\
\stackrel{े}{0} \\
\text { ô }\end{array}$ & & 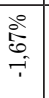 & $\stackrel{\circ}{\stackrel{0}{\circ}}$ & $\begin{array}{l}\text { के } \\
\text { के } \\
\text { के }\end{array}$ & $\begin{array}{l}\text { 今̊ } \\
\text { ô } \\
\text { ลิ }\end{array}$ & 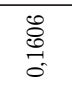 \\
\hline 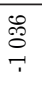 & 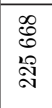 & 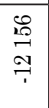 & $\begin{array}{l}\infty \\
\& \\
\stackrel{D}{*} \\
i \\
i\end{array}$ & $\begin{array}{l}\infty \\
\infty \\
\infty\end{array}$ & 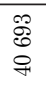 & $\begin{array}{l}\vec{\exists} \\
\text { 吾 }\end{array}$ & 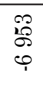 & $\begin{array}{l}\widehat{n} \\
\infty \\
\infty \\
10\end{array}$ & 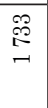 & $\begin{array}{l}20 \\
\Rightarrow 1 \\
0\end{array}$ & $\begin{array}{l}\stackrel{\mathscr{g}}{\leftrightarrows} \\
7\end{array}$ & 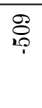 & \begin{tabular}{l}
$\overrightarrow{0}$ \\
0 \\
0 \\
\hdashline
\end{tabular} & 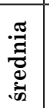 & 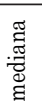 & 急 寻 & 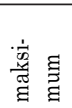 & 远 \\
\hline 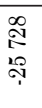 & 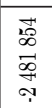 & 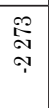 & 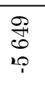 & 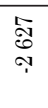 & \begin{tabular}{l}
\multirow{3}{*}{} \\
$\underset{\text { J }}{\mathrm{S}}$
\end{tabular} & & $\begin{array}{l}0 \\
\infty \\
\infty \\
\infty\end{array}$ & $\begin{array}{l}\overrightarrow{1} \\
0 \\
0 \\
10\end{array}$ & 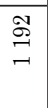 & $\begin{array}{l}0 \\
0 \\
0 \\
0\end{array}$ & 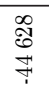 & 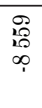 & $\begin{array}{l}\text { 공 } \\
\text { 공 }\end{array}$ & & & & & \\
\hline $\begin{array}{l}\text { Fै } \\
\text { J } \\
\infty \\
\infty\end{array}$ & 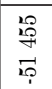 & $\begin{array}{l}\mathscr{0} \\
\infty \\
\infty \\
\infty\end{array}$ & 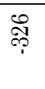 & $\begin{array}{l}\text { 吕 } \\
\text { 品 } \\
-1\end{array}$ & $\begin{array}{l}\underset{1}{1} \\
10\end{array}$ & & . & 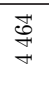 & 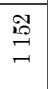 & $\begin{array}{l}\stackrel{P}{\circ} \\
\stackrel{2}{2} \\
o p\end{array}$ & H & $\begin{array}{l}\underset{\mathbb{N}}{\mathbb{N}} \\
\text { N̦ }\end{array}$ & & & & & & \\
\hline 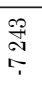 & 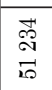 & . & 0 & $\begin{array}{l}0 \\
0 \\
0 \\
\forall\end{array}$ & $\begin{array}{l}\infty \\
\infty \\
\infty \\
\rightarrow+ \\
+\end{array}$ & & . & 芯 & 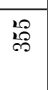 & \begin{tabular}{l}
$\stackrel{2}{2}$ \\
$\infty$ \\
\hdashline \\
\hdashline
\end{tabular} & $\begin{array}{l}\stackrel{q}{\mathbb{N}} \\
\therefore\end{array}$ & $\begin{array}{l}\infty \\
\infty \\
\infty \\
\vec{\sim}\end{array}$ & & & & & & \\
\hline 옹 & 总 & 声 & 总 & ڤิ & 灾 & 总 & 宫 & 窐 & 簋 & 能 & 吕 & $\stackrel{E}{E}$ & 公 & & & & & \\
\hline
\end{tabular}


Analiza wielkości miernika CSVspread w tabeli 2 pozwala na konstatację, że wielkopolskie spółki giełdowe w różnym stopniu przekazywały wartość właścicielom, przy czym 2013 r. był pod tym względem najlepszy dla akcjonariuszy wielkopolskich spółek giełdowych, a 2011 - najgorszy, gdyż tylko trzy spółki odnotowały w tym roku dodatni CSVspread (zarówno średnia, jak i mediana CSVspread była ujemna w 2011 r., a dodatnia w 2010 i 2013). Spośród wielkopolskich spółek giełdowych wskazać można takie, które we wszystkich latach zwiększały majątek swoich akcjonariuszy (EUR, PTI), jak również takie, które we wszystkich latach zubażały swoich właścicieli (np. DGA, INC, IZO). Jednak większość wielkopolskich spółek giełdowych w zróżnicowany sposób oddziaływała na majątek akcjonariuszy w poszczególnych latach badanego okresu. Zróżnicowanie badanych podmiotów pod względem wielkości miernika CSVspread przenosi się na ranking tych spółek, w którym brak stabilizacji w badanym okresie zarówno na pozycji lidera pod względem przekazywania wartości dla właścicieli, jak i na ostatnich miejscach rankingu.

Współczynniki korelacji liniowej Pearsona między zmiennymi REP a CSVspread w latach 2010-2013 przedstawiono w tabeli 3.

Tabela 3

Współczynniki korelacji liniowej Pearsona między zmiennymi REP a CSVspread

\begin{tabular}{|c|c|c|c|c|}
\hline Rok & $\mathbf{2 0 1 0}$ & $\mathbf{2 0 1 1}$ & $\mathbf{2 0 1 2}$ & $\mathbf{2 0 1 3}$ \\
\hline $\begin{array}{l}\text { Współczynnik korelacji liniowej Pearsona } \\
\text { (między zmiennymi REP a CSVspread) }\end{array}$ & 0,314776 & 0,210273 & 0,787296 & 0,274215 \\
\hline
\end{tabular}

Tylko współczynnik korelacji z 2012 r. jest istotny statystycznie z $p<0,05$.

Źródło: opracowanie własne.

Analiza danych zawartych $\mathrm{w}$ tabeli wskazuje na słabą korelację pomiędzy względnym zyskiem ekonomicznym a zmienną CSVspread wśród badanych spółek w latach 2010, 2011 i 2013. Jedynie w 2012 r. zaobserwowano dość silną i istotną statystycznie korelację między zmiennymi REP a CSVspread (tylko współczynnik korelacji odnotowany w 2012 r. jest istotny statystycznie z p<0,05). Oznacza to, że poza rokiem 2012 związek pomiędzy budową wartości przedsiębiorstwa a jej transferem do właścicieli jest słaby w wielkopolskich spółkach giełdowych. Innymi słowy, spółka budująca wartość niekoniecznie transferuje ja do swoich właścicieli, natomiast spółka niebudująca wartości może transferować wartość do właści- 
cieli. Z taką sytuacją mamy do czynienia wśród badanych spółek średnio w 2010 i 2013 r., kiedy spółki te, w ujęciu średnim, nie tworzyły wartości (średni ujemny REP), natomiast średni TSR przekraczał oczekiwaną stopę zwrotu. Zaobserwowane wyniki uzasadnić należy tym, że na przekazywanie wartości właścicielom oprócz efektów jej budowania wpływa wiele innych czynników. Część z nich jest wynikiem świadomej decyzji samej spółki (np. wypłata dywidendy), jednak duża ich część jest poza jej kontrola (np. psychologia rynku kapitałowego).

Obserwacje poczynione $\mathrm{w}$ odniesieniu do procesu budowania wartości przedsiębiorstwa $\mathrm{w}$ wielkopolskich spółkach giełdowych w kontekście teorii wyjaśniajacych pochodzenie zysków czystych każą skonstatować, że wśród tych podmiotów spółki otrzymujące wynagrodzenie za zmierzenie się z niekwantyfikowalną niepewnością są w mniejszości. Oznaczać to może, że większość spółek albo nie mierzy się z tą niepewnościa, albo mierząc się, nie otrzymuje za to wynagrodzenia (tzn. poważenie się na niepewność nie kończy się sukcesem). W odniesieniu do grupy poglądów zapoczątkowanych przez J. Schumpetera może to oznaczać, że prawdziwi innowatorzy, otrzymujący zapłatę za innowacje, są wśród wielkopolskich spółek giełdowych w mniejszości.

W kontekście powyższych ustaleń interesująca jest kwestia tego, jakie czynniki wpłynęły na zmiany zysku ekonomicznego w wielkopolskich spółkach giełdowych w badanym okresie. Analiza przyczynowa z wykorzystaniem metod deterministycznych zmierza do wskazania, w jakim stopniu poszczególne czynniki (zysk brutto, efektywna stopa podatku dochodowego, koszt kapitału własnego, kapitał własny) wpływają na odchylenie bezwzględne zmiennej objaśnianej (zysku ekonomicznego). Wyniki analizy przyczynowej przeprowadzonej metodą kolejnych podstawień przedstawiono w tabeli 4 .

Analiza danych zawartych w tabeli 4 pokazuje, że w całym badanym okresie na zmiany zysku ekonomicznego w wielkopolskich spółkach giełdowych największy wpływ miały zmiany zysku brutto. Wskazuje na to zarówno średnia, jak i mediana odchyleń cząstkowych (mediana sugeruje, że zmiany zysku brutto wyjaśniają zmiany zysku ekonomicznego w badanym okresie w ponad $70 \%$ ). Odnotowano znacznie mniejszy wpływ zmian kosztu kapitału własnego oraz zmian kapitału własnego, a najmniejszy wpływ zmian efektywnej stopy podatku dochodowego. Otrzymane wyniki sugerują zatem, że budowanie wartości wielkopolskich spółek giełdowych w największej mierze zdeterminowane zostało sferą operacyjną w połączeniu z przychodami i kosztami finansowymi ${ }^{42}$.

${ }^{42}$ Jak już wcześniej wspomniano, niezadowalająca jakość i stopień szczegółowości niektórych jednostkowych raportów finansowych w bazie danych Notoria uniemożliwiły całkowite rozdzielenie w analizie przyczynowej sfery operacyjnej od kosztów finansowania obcego i przychodów finansowych. 


\begin{tabular}{|c|c|c|c|c|c|c|c|c|c|c|c|c|c|c|c|c|c|c|c|}
\hline \multirow{3}{*}{ 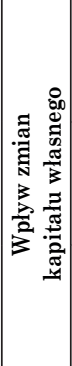 } & 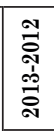 & 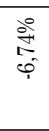 & 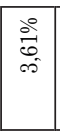 & 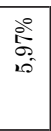 & $\begin{array}{l}\text { aे } \\
\text { à } \\
\text { ș }\end{array}$ & 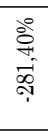 & $\begin{array}{l}\stackrel{\circ}{\circ} \\
\stackrel{\circ}{\circ}\end{array}$ & 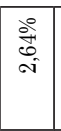 & $\begin{array}{c}\text { वें } \\
\text { aे } \\
\infty \\
\infty\end{array}$ & 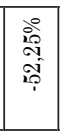 & \begin{tabular}{|c|}
$\stackrel{\circ}{\circ}$ \\
$\vec{b}$ \\
$-i$
\end{tabular} & 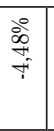 & $\begin{array}{l}\stackrel{0}{0}^{\circ} \\
\infty \\
0 \\
0\end{array}$ & $\begin{array}{l}\text { 今े } \\
\text { 今. } \\
\text { : } \\
\text { : }\end{array}$ & $\begin{array}{c}\stackrel{0}{0} \\
\stackrel{-}{-} \\
-1\end{array}$ & 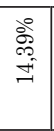 & 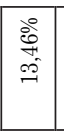 & 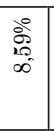 & 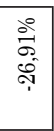 \\
\hline & 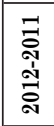 & 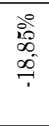 & 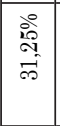 & 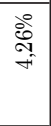 & $\begin{array}{l} \\
\stackrel{8}{\circ} \\
\overrightarrow{0}\end{array}$ & 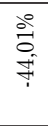 & $\begin{array}{l}\stackrel{0}{0} \\
\stackrel{0}{0} \\
\text { ơ }\end{array}$ & 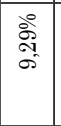 & 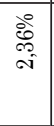 & 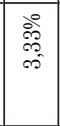 & 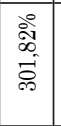 & 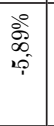 & 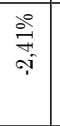 & 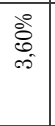 & \begin{tabular}{|c|}
0 \\
18 \\
$\sigma^{\circ}$
\end{tabular} & 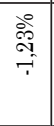 & 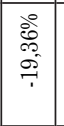 & 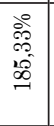 & 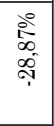 \\
\hline & 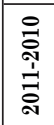 & 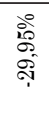 & \begin{tabular}{|l|}
0 \\
$\infty$ \\
$\infty$ \\
$=$ \\
$=$
\end{tabular} & 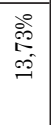 & & '. & 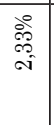 & 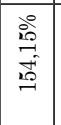 & 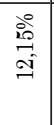 & 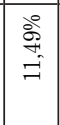 & 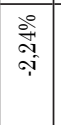 & 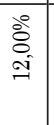 & $\begin{array}{l}\text { 今े } \\
\text { ठ․ } \\
8\end{array}$ & 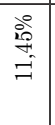 & 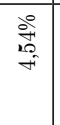 & $\begin{array}{l}\stackrel{\circ}{\stackrel{0}{a}} \\
\exists\end{array}$ & $\begin{array}{l}0 \\
\text { 今. } \\
0 \\
0\end{array}$ & 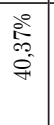 & 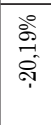 \\
\hline \multirow{3}{*}{ 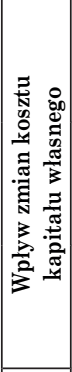 } & 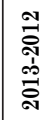 & 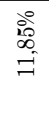 & 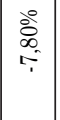 & $\begin{array}{l}\text { 今े } \\
\text { ôे } \\
\text { à }\end{array}$ & 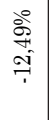 & 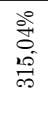 & 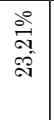 & 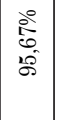 & 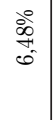 & 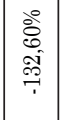 & \begin{tabular}{|l|}
80 \\
8 \\
80 \\
$\circ$
\end{tabular} & \begin{tabular}{l} 
๖े \\
\multirow{7}{*}{} \\
जे
\end{tabular} & 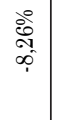 & 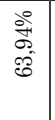 & 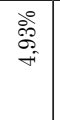 & 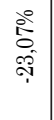 & 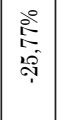 & 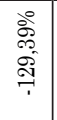 & 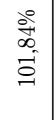 \\
\hline & 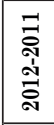 & 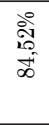 & \begin{tabular}{|l|}
\multirow{2}{0}{} \\
5 \\
5 \\
5 \\
5
\end{tabular} & 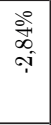 & 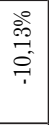 & 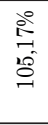 & 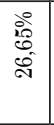 & 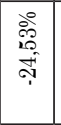 & 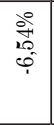 & 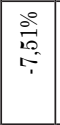 & 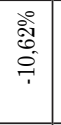 & \begin{tabular}{l|}
$\stackrel{\circ}{\circ}$ \\
$\stackrel{\circ}{\circ}$
\end{tabular} & 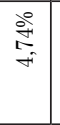 & 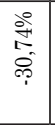 & 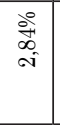 & 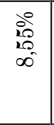 & 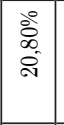 & 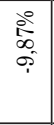 & \begin{tabular}{|l|}
$\stackrel{0}{\circ}$ \\
$\overrightarrow{\tilde{\sigma}}$ \\
\multirow{\gamma}{*}{}
\end{tabular} \\
\hline & 章 & 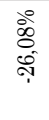 & 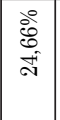 & 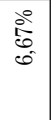 & . & $\cdot$ & 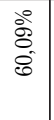 & 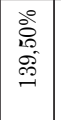 & 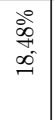 & 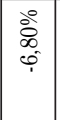 & 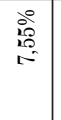 & 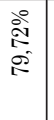 & $\begin{array}{l}\stackrel{\circ}{\circ} \\
\infty \\
\stackrel{\infty}{1}\end{array}$ & 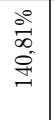 & 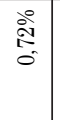 & 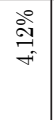 & 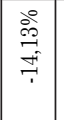 & 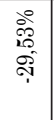 & 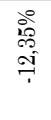 \\
\hline \multirow{3}{*}{ 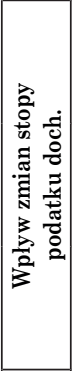 } & 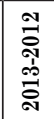 & 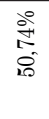 & 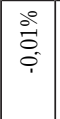 & 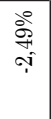 & 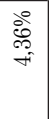 & $\begin{array}{l}\text { 总 } \\
18 \\
10 \\
0 \\
0\end{array}$ & 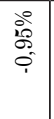 & \begin{tabular}{|l|}
0 \\
$\stackrel{\circ}{\Rightarrow}$ \\
$\infty \infty^{\circ}$ \\
$\infty$
\end{tabular} & $\begin{array}{l}\stackrel{0}{0} \\
\dot{0} \\
\stackrel{0}{0}\end{array}$ & 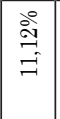 & 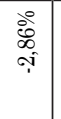 & 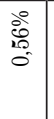 & 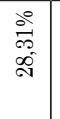 & 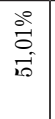 & 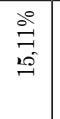 & 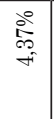 & 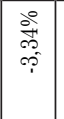 & 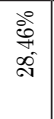 & 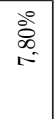 \\
\hline & 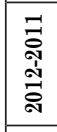 & 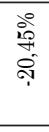 & 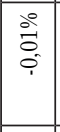 & 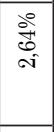 & 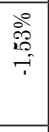 & 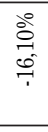 & 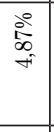 & \begin{tabular}{|l|}
0 \\
0 \\
0 \\
0 \\
0 \\
\end{tabular} & 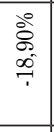 & 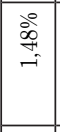 & \begin{tabular}{|c|} 
字 \\
- \\
-1
\end{tabular} & 章 & $\begin{array}{l}\text { 今े } \\
\text { 今 } \\
\text { 今 }\end{array}$ & 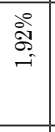 & 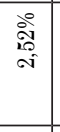 & 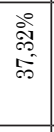 & 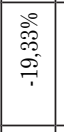 & 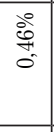 & $\begin{array}{l}0 \\
i 0 \\
10 \\
0 \\
10\end{array}$ \\
\hline & 疍 & 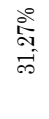 & 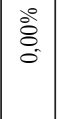 & \begin{tabular}{|l|}
2 \\
20 \\
10 \\
0 \\
0
\end{tabular} & & . & 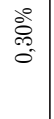 & 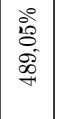 & 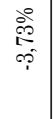 & \begin{tabular}{|l|}
0 \\
0 \\
0 \\
0
\end{tabular} & 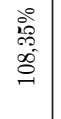 & 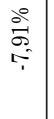 & $\begin{array}{l}\stackrel{\circ}{\mathrm{E}} \\
\stackrel{-}{\mathrm{A}}\end{array}$ & 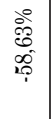 & 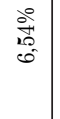 & 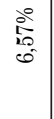 & 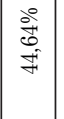 & $\begin{array}{l}\stackrel{0}{0} \\
\vdots \\
0\end{array}$ & 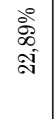 \\
\hline \multirow{3}{*}{ 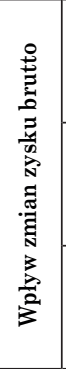 } & 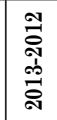 & $\begin{array}{l}\stackrel{\circ}{\circ} \\
\text { \& }\end{array}$ & 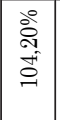 & $\begin{array}{l}\grave{0} \\
\stackrel{0}{\circ} \\
\infty\end{array}$ & 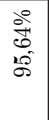 & $\begin{array}{l}\circ \\
\stackrel{\circ}{\sigma} \\
0 \\
0 \\
0\end{array}$ & $\begin{array}{l}\text { 总 } \\
\stackrel{8}{\circ} \\
\stackrel{0}{1}\end{array}$ & 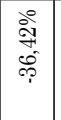 & 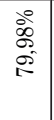 & 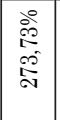 & \begin{tabular}{|l|}
0 \\
is \\
is \\
if \\
\end{tabular} & 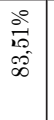 & $\begin{array}{l}\stackrel{\circ}{\stackrel{\circ}{y}} \\
\hat{g}\end{array}$ & 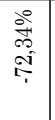 & $\begin{array}{l}\mid \\
\hat{\sigma}_{0}^{\circ} \\
0^{\circ}\end{array}$ & 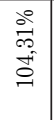 & 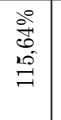 & 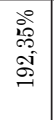 & 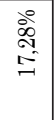 \\
\hline & $\begin{array}{l}\text { 콩 } \\
\text { 今ิ } \\
\text { जิ } \\
\text { ลิ }\end{array}$ & 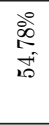 & 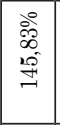 & 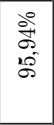 & 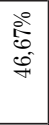 & 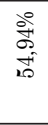 & 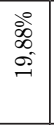 & 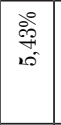 & 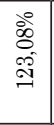 & 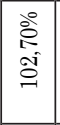 & 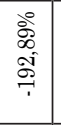 & 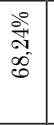 & $\begin{array}{l}\text { 高 } \\
\text { ơ } \\
\stackrel{0}{2}\end{array}$ & 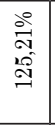 & \begin{tabular}{|l|}
$\infty$ \\
$\infty$ \\
$\infty$ \\
$\infty$ \\
$\infty$
\end{tabular} & 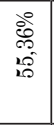 & \begin{tabular}{l|}
$\stackrel{0}{\circ}$ \\
$\infty$ \\
$\stackrel{-}{=}$ \\
$=$
\end{tabular} & 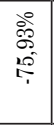 & 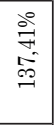 \\
\hline & 올 & 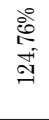 & 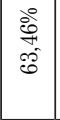 & $\begin{array}{l}\text { वें } \\
\text { के } \\
\rho^{\circ}\end{array}$ & & . & 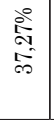 & 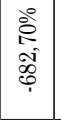 & 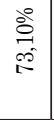 & $\begin{array}{l}80 \\
10 \\
20 \\
0\end{array}$ & 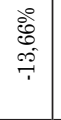 & $\begin{array}{l}\text { 今े } \\
\text { ड़ }\end{array}$ & 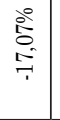 & 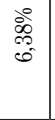 & $\begin{array}{l}\text { aें } \\
\infty \\
\infty \\
\infty\end{array}$ & 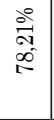 & 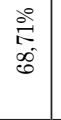 & $\mid \begin{array}{l}0 \\
0 \\
0 \\
0 \\
\infty \\
\infty \\
\infty \\
\infty\end{array}$ & $\begin{array}{l}80 \\
80 \\
8 \\
8 \\
0 \\
0\end{array}$ \\
\hline \multirow{3}{*}{ 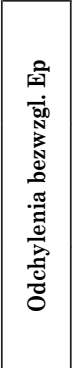 } & 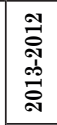 & 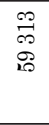 & \begin{tabular}{|l|}
0 \\
0 \\
10 \\
00 \\
7
\end{tabular} & \begin{tabular}{|l|}
\multirow{0}{0}{} \\
0 \\
0 \\
\hdashline
\end{tabular} & 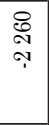 & 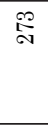 & $\begin{array}{l}0 \\
0 \\
0 \\
0 \\
i n م\end{array}$ & \begin{tabular}{|l|l}
\multirow{N}{*}{} \\
N \\
\end{tabular} & $\begin{array}{l} \\
0 \\
0 \\
0 \\
0\end{array}$ & 郘 & $\begin{array}{l}8 \\
8 \\
10\end{array}$ & 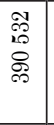 & 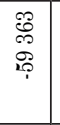 & 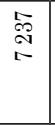 & \begin{tabular}{l|l|}
$\infty$ & 0 \\
$\infty$ \\
$=$ \\
$=$
\end{tabular} & 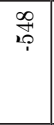 & $\begin{array}{l}\overrightarrow{\text { Jे }} \\
0 \\
0\end{array}$ & \begin{tabular}{|l|}
$\stackrel{g}{\mid}$ \\
$\stackrel{9}{9}$
\end{tabular} & \begin{tabular}{|l|}
$\infty$ \\
$\stackrel{\infty}{0}$ \\
-1 \\
-1
\end{tabular} \\
\hline & $\begin{array}{l}\text { 콩 } \\
\text { 今ิ } \\
\text { जี } \\
\text { ลิ }\end{array}$ & 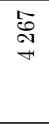 & $\begin{array}{l}\text { 年 } \\
\text { 要 }\end{array}$ & 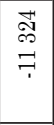 & \&. & $\begin{array}{l}\text { @ } \\
\text { î } \\
\text { N }\end{array}$ & \begin{tabular}{l|}
$\overrightarrow{0}$ \\
d \\
a
\end{tabular} & \begin{tabular}{|c|}
\multicolumn{2}{|c|}{} \\
$\stackrel{2}{5}$ \\
$\infty$ \\
\end{tabular} & 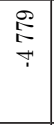 & 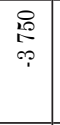 & 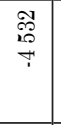 & 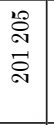 & $\begin{array}{l}\mathcal{F} \\
\mathbb{N} \\
\infty \\
\infty\end{array}$ & \begin{tabular}{l|}
$\stackrel{9}{0}$ \\
0 \\
1
\end{tabular} & 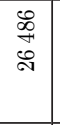 & $\vec{\infty}$ & 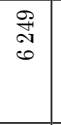 & 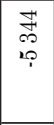 & 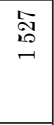 \\
\hline & 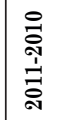 & 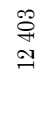 & \begin{tabular}{|l|}
\multirow{2}{*}{} \\
0 \\
0 \\
\hdashline
\end{tabular} & 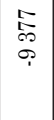 & & . & 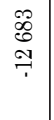 & 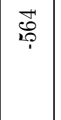 & $\begin{array}{l}\underset{q}{f} \\
\underset{i}{\prime}\end{array}$ & $\begin{array}{l}8 \\
2 \\
7\end{array}$ & 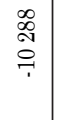 & 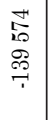 & $\begin{array}{l}\stackrel{\text { J }}{\mathrm{N}} \\
\text { H }\end{array}$ & $\begin{array}{l}\overrightarrow{\overrightarrow{5}} \\
\stackrel{9}{7}\end{array}$ & $\begin{array}{l}0 \\
\vdots \\
9 \\
+ \\
1\end{array}$ & $\begin{array}{l}\stackrel{0}{9} \\
\Rightarrow \\
\Rightarrow\end{array}$ & $\begin{array}{l}\overrightarrow{0} \\
\tilde{0} \\
0 \\
0\end{array}$ & \begin{tabular}{|l|}
$\infty$ \\
\multirow{1}{*}{} \\
N
\end{tabular} & 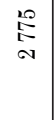 \\
\hline \multicolumn{2}{|c|}{ 葛 } & $\sum_{4}^{0}$ & $\begin{array}{l}0 \\
\\
\end{array}$ & 安 & 定 & D & 8 & 串 & 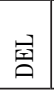 & 芯 & 号 & 至 & 点 & Z & 导 & $\mathbb{N}$ & $\sum_{01}$ & 衰 & 족 \\
\hline
\end{tabular}




\begin{tabular}{|c|c|c|c|c|c|c|c|c|c|c|c|c|c|c|c|c|c|}
\hline $\overrightarrow{\mathrm{N}}$ & 吕 & 高 & 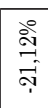 & $\begin{array}{l}20 \\
\stackrel{2}{2} \\
26 \\
0\end{array}$ & 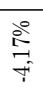 & 商 & $\begin{array}{l}\stackrel{\circ}{+} \\
\stackrel{+}{\rightarrow}\end{array}$ & $\begin{array}{l}\text { 今े } \\
0 \\
0\end{array}$ & $\begin{array}{l}\stackrel{0}{\infty} \\
\stackrel{0}{0}\end{array}$ & \begin{tabular}{|l|}
\multirow{a}{*}{} \\
à \\
\end{tabular} & $\begin{array}{l}\text { @े } \\
\stackrel{0}{0} \\
0\end{array}$ & 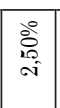 & 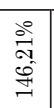 & 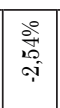 & 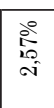 & \begin{tabular}{|l|}
$\stackrel{0}{ }$ \\
$\vec{H}$ \\
0 \\
$\stackrel{0}{\sim}$
\end{tabular} & 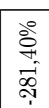 \\
\hline \&o & $\begin{array}{l}\text { वें } \\
\text { जे } \\
\text { o. }\end{array}$ & $\begin{array}{l}80 \\
0^{\circ} \\
0^{\circ} \\
0^{\circ}\end{array}$ & 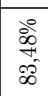 & 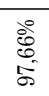 & $\begin{array}{l}\stackrel{\circ}{0} \\
\stackrel{0}{-1}\end{array}$ & & & 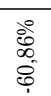 & 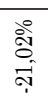 & 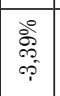 & 哭 & \begin{tabular}{|c|}
$\stackrel{2}{\circ}$ \\
$\stackrel{+}{+}$ \\
\multirow{+}{*}{} \\
\end{tabular} & & 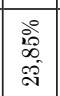 & 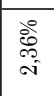 & 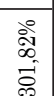 & $\begin{array}{l}0 \\
0 \\
0 \\
0 \\
\\
\end{array}$ \\
\hline$\stackrel{8}{\circ}$ & $\begin{array}{l}0 \\
0 \\
0 \\
0 \\
0 \\
0\end{array}$ & ' & 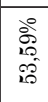 & $\begin{array}{l}\stackrel{0}{\circ} \\
\infty \\
8 \\
8\end{array}$ & $\begin{array}{l}\text { बे } \\
\stackrel{0}{0} \\
\text { ते }\end{array}$ & & . & $\begin{array}{l}\circ \\
\stackrel{8}{\circ} \\
\stackrel{9}{-}\end{array}$ & 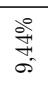 & 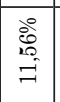 & 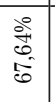 & 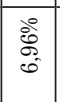 & ' & 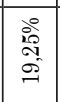 & 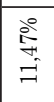 & 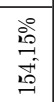 & 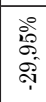 \\
\hline id & $\begin{array}{l}\text { 总 } \\
\text { : }\end{array}$ & 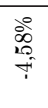 & 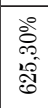 & $\begin{array}{l}\text { 吕 } \\
\text { के } \\
\text { of }\end{array}$ & $\begin{array}{l}\text { के̀े } \\
\text { वें }\end{array}$ & $\begin{array}{l}\text { ठें } \\
\text { o. }\end{array}$ & 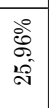 & 㞼 & 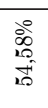 & $\begin{array}{l}\text { సें } \\
\text { సू. }\end{array}$ & $\begin{array}{l}\stackrel{\circ}{\circ} \\
\stackrel{0}{\circ} \\
0^{\circ}\end{array}$ & 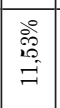 & 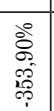 & 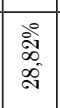 & 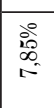 & 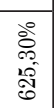 & 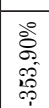 \\
\hline 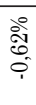 & 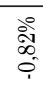 & 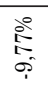 & 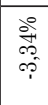 & $\begin{array}{l}\stackrel{\circ}{\circ} \\
\stackrel{0}{+} \\
+\end{array}$ & 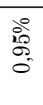 & & ' & 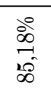 & 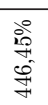 & 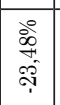 & 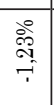 & 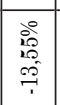 & . & 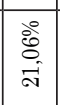 & ๙े & 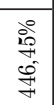 & 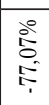 \\
\hline ing & 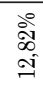 & & \begin{tabular}{|l}
0 \\
7 \\
7 \\
6 \\
$o f$
\end{tabular} & 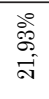 & $\begin{array}{l}\text { बें } \\
\infty \\
\sigma^{\circ}\end{array}$ & & . & 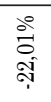 & $\begin{array}{l}0 \\
\stackrel{0}{0} \\
\stackrel{0}{0}\end{array}$ & 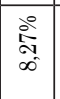 & \begin{tabular}{l}
$\stackrel{\circ}{\circ}$ \\
\multirow{-}{*}{}
\end{tabular} & 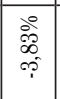 & . & 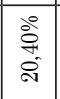 & 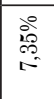 & 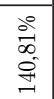 & 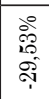 \\
\hline ثें & 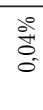 & $\begin{array}{l}\text { 产 } \\
\stackrel{1}{\hat{a}} \\
\text { a }\end{array}$ & 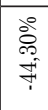 & 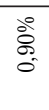 & 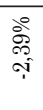 & $\begin{array}{l} \\
\stackrel{0}{0} \\
0^{\circ}\end{array}$ & 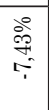 & 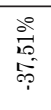 & $\begin{array}{l}\ddot{\circ} \\
\ddot{\circ} \\
\overbrace{}^{\circ}\end{array}$ & 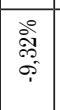 & 今్ & 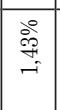 & \begin{tabular}{l|}
$\stackrel{0}{0}$ \\
$\infty$ \\
$\stackrel{0}{+}$ \\
$\stackrel{+}{+}$
\end{tabular} & \begin{tabular}{|l|}
$\stackrel{0}{\circ}$ \\
$\stackrel{0}{0}$ \\
$-i$
\end{tabular} & $\stackrel{8}{\circ}$ & 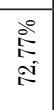 & 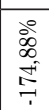 \\
\hline $\begin{array}{l}\stackrel{\circ}{\circ} \\
\text { ले } \\
0 \\
0\end{array}$ & $\begin{array}{l}\text { 今े } \\
\text { సे }\end{array}$ & 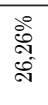 & 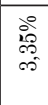 & 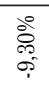 & 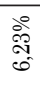 & & . & 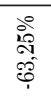 & 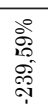 & 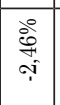 & 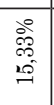 & 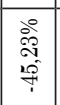 & ' & 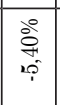 & 今. & 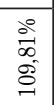 & 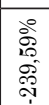 \\
\hline 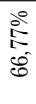 & $\begin{array}{l}\text { oे } \\
\infty \\
0 \\
0 \\
0\end{array}$ & . & 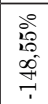 & $\begin{array}{l}\stackrel{0}{\circ} \\
\stackrel{7}{\circ}\end{array}$ & 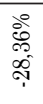 & & . & $\begin{array}{l}\text { वें } \\
\text { aे } \\
\text { ๙े }\end{array}$ & $\begin{array}{l}\overrightarrow{0} \\
\vec{\sigma} \\
0 \\
0 \\
0\end{array}$ & 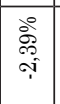 & 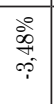 & 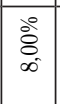 & . & $\mid \begin{array}{c}0 \\
\text { ô } \\
-1 \\
-1\end{array}$ & $\begin{array}{l}0 \\
00 \\
0 \\
0\end{array}$ & 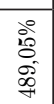 & 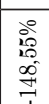 \\
\hline 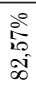 & $\begin{array}{l}\text { बें } \\
\text { बें }\end{array}$ & 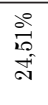 & 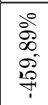 & 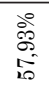 & 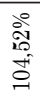 & 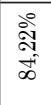 & 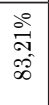 & 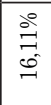 & 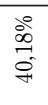 & \begin{tabular}{|l|}
$\circ 0$ \\
$\delta$ \\
5 \\
5 \\
5 \\
\end{tabular} & 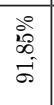 & 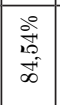 & 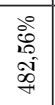 & \begin{tabular}{|c|}
0 \\
18 \\
$\infty$ \\
1 \\
11
\end{tabular} & $\begin{array}{l} \\
\stackrel{\infty}{\infty} \\
\infty \\
\infty\end{array}$ & 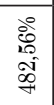 & 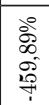 \\
\hline 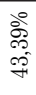 & के & 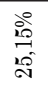 & 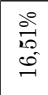 & 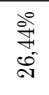 & $\begin{array}{l}\text { 勇 } \\
\stackrel{8}{\circ}\end{array}$ & & . & 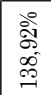 & $\begin{array}{l}\AA^{\circ} \\
10 \\
10 \\
10 \\
0\end{array}$ & 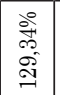 & 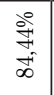 & 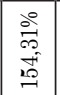 & . & 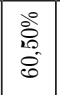 & 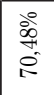 & 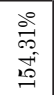 & 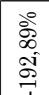 \\
\hline 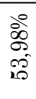 & $\begin{array}{l}\text { ลे̀ } \\
\text { fै }\end{array}$ & & 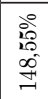 & 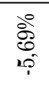 & $\begin{array}{l}\text { वें } \\
\text { o. } \\
\stackrel{0}{0}\end{array}$ & & . & $\begin{array}{l}\AA_{0}^{\circ} \\
8 \\
8 \\
8\end{array}$ & $\begin{array}{l}0 \\
\stackrel{0}{\circ} \\
\stackrel{5}{\infty} \\
\infty\end{array}$ & 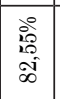 & 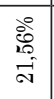 & \begin{tabular}{|l|}
80 \\
$\infty$ \\
$\infty$ \\
$\infty$ \\
$\infty$
\end{tabular} & . & 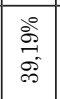 & $\begin{array}{l}8 \\
88 \\
18 \\
10 \\
20\end{array}$ & 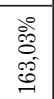 & 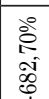 \\
\hline $\begin{array}{l}\text { 今े } \\
\text { J }\end{array}$ & 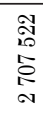 & $\begin{array}{l}\vec{D} \\
\infty \\
\infty \\
\sigma_{0}\end{array}$ & $\because$ & 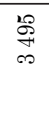 & 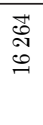 & 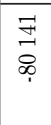 & $\begin{array}{l}\stackrel{P}{R} \\
\stackrel{5}{\circ} \\
?\end{array}$ & î & $\underset{10}{7}$ & \begin{tabular}{|l|}
$\vec{\omega}$ \\
$\vec{\sigma}$
\end{tabular} & 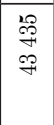 & \begin{tabular}{|l|l} 
\\
$\qquad$ \\
0 \\
$\infty$
\end{tabular} & 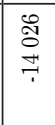 & 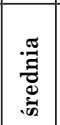 & 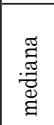 & $\underset{\Xi}{\stackrel{\varpi}{\Xi}}$ & 寻 \\
\hline$\varnothing$ & 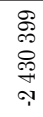 & $\underset{+}{\stackrel{7}{\rightarrow}}$ & 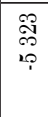 & 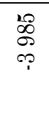 & 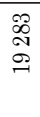 & & & ช్ & P & \begin{tabular}{|l|} 
\\
$\stackrel{\sim}{N}$ \\
\multirow{1}{*}{}
\end{tabular} & 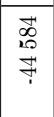 & 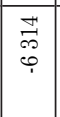 & & & & & \\
\hline 8 & 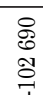 & & 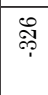 & 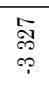 & $\not \circ$ & & . & 灾 & so & 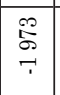 & \begin{tabular}{|l|}
8 \\
8 \\
\hdashline \\
\end{tabular} & \begin{tabular}{|l|}
\multirow{7}{*}{} \\
\\
9 \\
\end{tabular} & & & & & \\
\hline & $\begin{array}{l}\breve{J} \\
\stackrel{0}{0}\end{array}$ & 周 & 若 & ڤै & 灾 & 兽 & $\overrightarrow{\sigma_{n}}$ & 皇 & 垉 & 层 & $\begin{array}{l}u \\
W \\
G\end{array}$ & $\begin{array}{l}\varphi^{2} \\
02 \\
3\end{array}$ & 窐 & & & & \\
\hline
\end{tabular}




\section{PODSUMOWANIE}

W artykule przedstawiono wyniki badania efektywności wielkopolskich spółek giełdowych. Podjęta problematyka wpisuje się w szeroko rozumiane zagadnienie zarządzania miastem, jeśli weźmie się pod uwagę fakt, że efektywność przedsiębiorstw w regionie jest elementem warunkujacym rozwój regionalny, jak również rozwój miasta, a rozpoznanie i wspieranie potencjału gospodarczego terytorium, także w kontekście atrakcyjności miasta i obszaru metropolitalnego, stanowi jeden z kluczowych problemów zarządzania miastem. Ponadto efektywność przedsiębiorstw ma wpływ na możliwości finansowe zarządzających miastem, jak również tworzenie miejsc pracy oraz klimatu inwestycyjnego.

Aby dokonać pomiaru i interpretacji osiagnięć wielkopolskich spółek giełdowych w zakresie realizacji celu działania przedsiębiorstwa według koncepcji zarządzania przez wartość, przedstawiono i zinterpretowano wyniki obliczeń zysku ekonomicznego, względnego zysku ekonomicznego oraz miernika CSVspread. Wskazano także determinanty zmian wartości przedsiębiorstwa, wykorzystując do tego celu jedna z metod deterministycznych w analizie ekonomicznej przedsiębiorstwa.

Wyniki badania pokazuja, że większość wielkopolskich spółek giełdowych nie budowała wartości przedsiębiorstwa w analizowanym okresie, co oznacza, iż wygenerowane przez nie stopy zwrotu były niższe od kosztu kapitału. Odniesienie tych wyników do teorii wyjaśniajacych pochodzenie zysków czystych usprawiedliwia stwierdzenie, że wśród wielkopolskich spółek giełdowych mniejszość stanowią prawdziwi innowatorzy, otrzymujący wynagrodzenie za innowacje czy spółki otrzymujące zapłatę za zmierzenie się z niekwantyfikowalną niepewnościa. Analizowane spółki zwiększały majątek swoich właścicieli w średnim ujęciu tylko w 2010 i 2013 r. Oznacza to, że w latach 2011-2012 całkowity zwrot dla akcjonariuszy wygenerowany przez wielkopolskie spółki giełdowe był niższy od oczekiwanego. Stwierdzić jednak trzeba, że analizowane podmioty wykazywały duże zróżnicowanie w badanym okresie zarówno pod względem względnego zysku ekonomicznego, jak i miernika CSVspread. Analiza danych charakteryzujacych wielkopolskie spółki giełdowe wykazała dość silną i istotną statystycznie korelację między wynikami budowy wartości przedsiębiorstwa a rezultatami jej transferu do właścicieli tylko w 2012 r. W pozostałych latach zależność ta była słaba i nieistotna statystycznie. Natomiast analiza przyczynowa wykazała, że zmiany zysku ekonomicznego w badanym okresie w największym stopniu determinowane są zmianami zysku brutto.

Uzyskane wyniki pokazują zróżnicowaną kondycję wielkopolskich spółek giełdowych pod względem tworzenia wartości. Wskazówki co do dalszych badań obejmują ich rozszerzenie na większą grupę wielkopolskich przedsiębiorstw bez ograniczania się do spółek giełdowych, co mogłoby umożliwić wnioskowanie uogólniające, jak również wprowadzenie do analizy dodatkowych zmiennych, to z kolei przy poprawie jakości danych używanych w obliczeniach mogłoby umożliwić wyłonienie bardziej szczegółowych determinant wartości.

dr Jarostaw Nowicki

Uniwersytet Ekonomiczny w Poznaniu

j.nowicki@ue.poznan.pl 


\section{CREATING VALUE IN WIELKOPOLSKA LISTED COMPANIES}

\section{Sum mary}

The article presents the findings of research conducted into companies from the Wielkopolska region listed on the Warsaw Stock Exchange (WSE). The study explores whether these entities create value and transfer it to the shareholders, and whether the effects of the value creation process are correlated with value transfer to shareholders. The study also identifies the main determinants of corporate value changes.

The results show that most companies from the Wielkopolska region listed on WSE did not create corporate value in the analysed period. This means that returns on equity generated by them was lower than the cost of capital.

Companies from the Wielkopolska region listed on the WSE transferred value to their shareholders, on average, in 2010 and 2013 which means that in 2011 and 2012 the total shareholder return generated by those companies was lower than expected. However the study shows large diversity among analysed companies in terms of relative economic profit (REP) as well as created shareholder value spread (CSVspread). Analysis of the data indicates a low correlation between REP and CSVspread variables among the analysed companies in 2010-11 and 2013. Only year 2012 showed a relatively strong and statistically significant correlation between variables REP and CSVspread. Analysis showed that the most important determinant of changes in economic profit is gross profit. The influence of other variables, i.e. equity, the effective income tax rate and the cost of equity is much smaller. 
